\title{
COMPARATIVE DIETARY VALUE OF SOYBEAN OII, SUNFIOWER OIL, RAPESEED OIL AND ANIMAL TALLOW FOR TURKEY POULTS
}

\author{
A Thesis \\ Presented to \\ The Faculty of Graduate Studies and Research \\ University of Manitoba
}

In Partial pulfillment of the Requirements for the Degree Master of Science

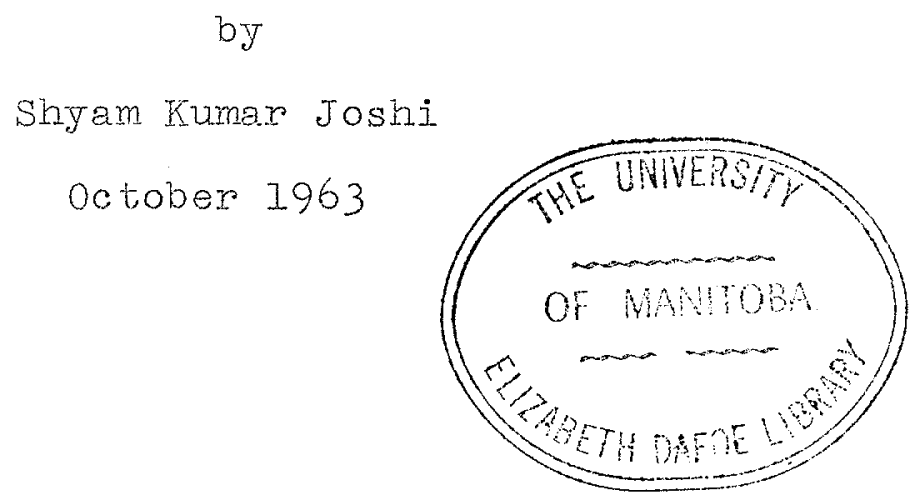




\section{ACKNOWLEDGEMENTS}

For making this work possible as well as helping in its planning and execution, the author is particularly indebted to Dr. JoI. Sell. The helpful criticisms, and counsel of Prof.G.C.Hodgson, of the Department of Animal Science, University of Manitoba is also appreciated.

The efforts of Mir. Steve Antonation, Poultry Foreman and of Mr. William Guenter in the care and management of the birds during this investigation is gratefully acknowledged. This project was assisted by a grant, from National Research Council of Canada for which the author is grateful. 
TABLE: OF CONTENTS

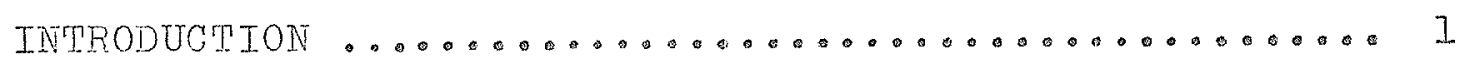

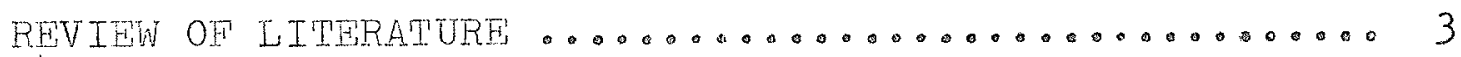

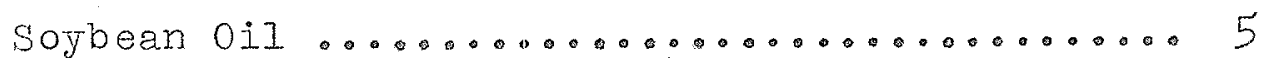

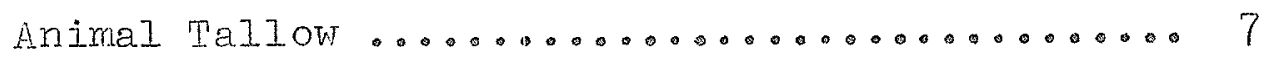

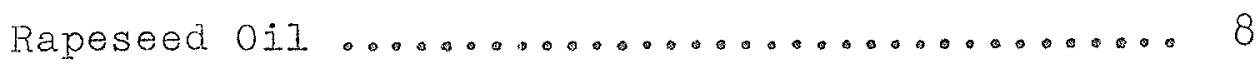

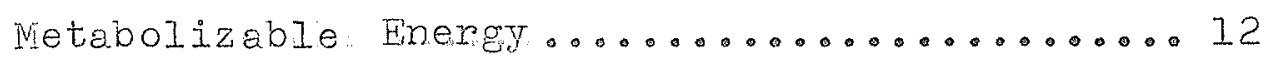

Effect of Dietary Fat on Tissue Fat ......... 13

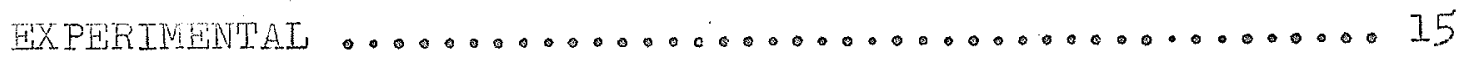

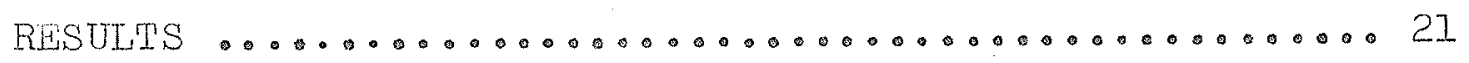

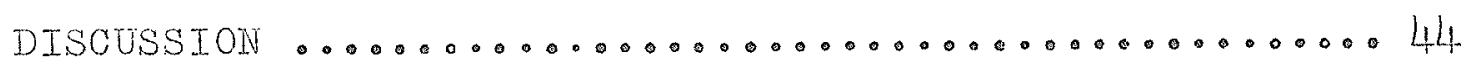

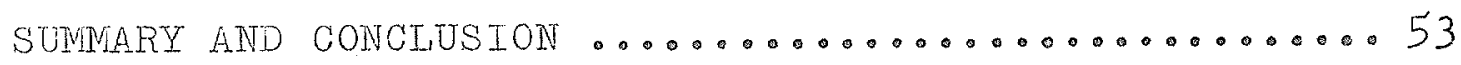

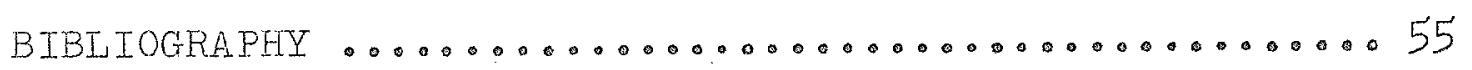

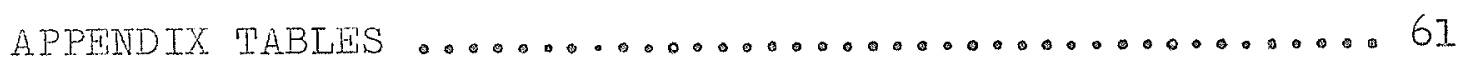




\section{LIST OF TABLES}

TABLE

PAGE

I Composition of The 29\% And 21\% Protein Basal Starting And Growing Ration ......... 17

II Comparative Effects of Dietary fiats on Weight Gain of Turkeys From 0 To 4 Weeks of Age.. 22

II Comparative Effects of Dietary Fats on Efficiency of Feed Utilization of Turkeys From 0 To 4 Weeks of Age .............. 23

IV Comparative Efrects of Dietary Fats on Weight Gain of Turkeys From 0 To 6 Weeks of Age.. 24

$V$ Comparative Effects of Dietary Fats on Efficiency Of Fied Utilization of Turkeys From 0 To 6

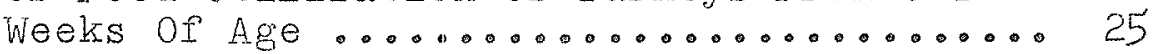

VI Comparative Effects of Dietary Fats on Feed Consumption of Turkeys From 0 To 6 weeks of

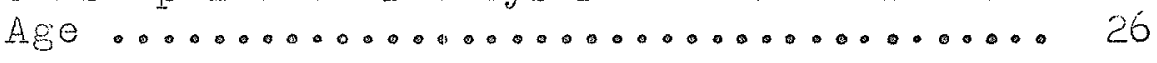

VII Comparative Effects of Dietary Fats on weight Gain of Turkeys From 0 To 12 Weeks of Age.. 28

VIII Comparative Effects of Dietary Fats on Eficiency of Feed Utilization of Turkeys From 0 To 12 Weeks of Age ............ 29

IX Comparative Effects of Dietary Fats On Weight Gain of Turkeys From O To 16 Weeks of Age. 31

$X$ Comparative Effects of Dietary Frats on Efriciency of Feed Utilization of Turkeys From 0 To 16 Weeks of Age ............ 32

XI Comparative Effects of Dietary Fats on Feed Consumption Of Purkeys From 0 To 16 Weeks

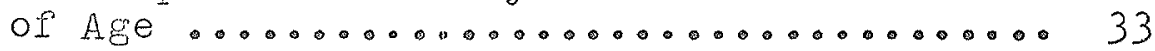

XII Metabolizable Energy And Nitrogen Retention of Rations Containing Different Fat Sources As Determined With Turkey Poults From 5 To 6 weeks of Age ............. 36 
XII Elfect of Added Dietary Fats on Blood Serum Cholesterol Levels of Turkeys ............ 38

XIV Dressing Percent And Carcass Grades of 16 weeks

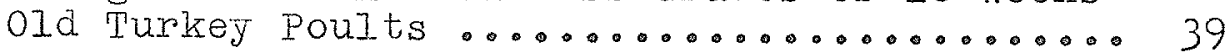

XV Effect of Aded Dietary Fat on Tissue Fat And on The Iodine Values of Abdominal Adipose Tissue of 16-week-01d Turkeys ...........4 4 I

XVI Fatty Acid Composition of Fat Sources Used in Rations And Abdominal Adipose Tissue of 16-Week-01a Turkey Poults .............. 42 
IIST OF FIGURES

NUNBBER

PAGE

1.

Comparative Effects of Fats on Weight

Gain When Fed As 10 Percent of The

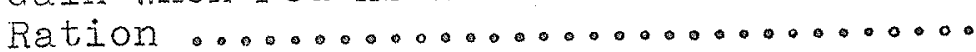


APPENDIX TABLES

TABLE

PAGE

1. Comparative Effects of Dietary Tat on Weight Gains

62

2. Comparative Effects of Dietary Fats on Ffficiency of Feed Utilization

3. Analysis of Variance of Weight Gains And Feed

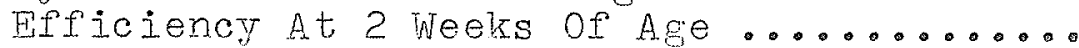

64

4. Analysis of Variance of Weight Gains And Feed

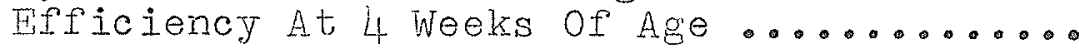

5. Analysis of Variance of Weight Gains And Feed

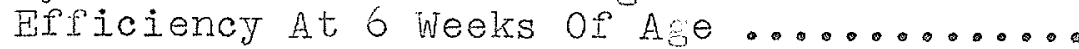

6. Analysis of Variance of weight Gains And Feed Efficiency At 8 Weeks of $A g e \ldots . . . . . . .$.

7. Analysis of Variance of weight Gains And Feed Ffficiency At 12 weeks of Age ........... 68

8. Analysis of Variance of Weight Gain And Feed

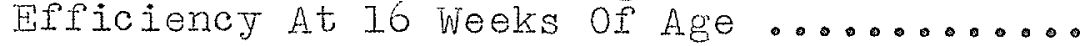

9. Analysis of Variance of Metabolizable Energy And Nitrogen Retention of Rations Containing Different Fat Sources As Determined With Turkey Poults Erom 5 To 6 Weeks of Age ...

10. Analysis of Variance For Ether Extracts of Pectorlis Minor And Gastrocnemius Muscles.

11. Analysis of Variance on Blood Serum Cholesterol

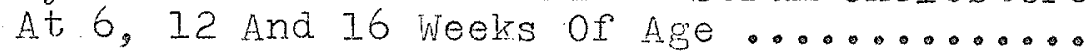

12. Analysis of Variance of The Transformed Dato Pertaining To Dressed Weight And Carcass crades As A Percentage of Live weight....

13. Analysis of Variance on the Iodine Values of Abdominal Adipose Tissue 
Comparative Dietary Value of Soybean Oil, Sunflower Oil, Rapeseed oil And Animal Tallow For Turkey Poults

by

Shyam Kumar Joshi

ABSTRACT

The effect of including soybean oil, sunflower oil, rapeseed oil or animal tallow in turkey poult rations was studied. These fat sourceg were tested at $5 \%$ and $10 \%$ of the ration. Male Broad Breasted Bronze poults were used in this study. Each experimental ration was assigned to 3 experimental pens according to a randomized block design. Each experimental pen contained 11 poults. At 6 weeks of age, all poults on each of the nine treatments were pooled together and were reasigned to 18 floor pens; thus each treatment was applied to two experimental pens. Feed and water were supplied ad libitium. The experiment was terminated when the poults were 16 weeks of age. The following criteria were used to compare the effects of dietary soybean oil, sunflower oil, rapeseed oil and animal tallow on the performance of turkey poults; growth rate, efriciency of feed utilization, metabolizable energy content of rations and fat deposition in the muscle tissue of the carcass. 
viii

Data collected indicate that the addition of soybean oil, sunflower oil or animal tallow to a low pat ration stimulated weight gain and improved efficiency of feed utilization. The ration containing 10\% soybean oil was the only exception to the above so far as weight gain was concerned but this ration significantly improved efficiency of feed utilization. The addition of rapeseed oil to the ration depressed weight gain throughout the experiment as compared to the basal (low-fat) ration. The magnitude of growth depression was directly related to the rapeseed oil content of the ration. The comparative ration metabolizable energy data indicate that the dietary energy supplied by rapeseed oil was as available to poults as energy supplied by other fat sources. Poults consuming rations containing $5 \%$ or $10 \%$ rapeseed oil consumed significantly less feed than did poults fed the basal ration. Depressed weight gains by poults on rapeseed oil rations was apparentily due to decreased feed consumption.

No significant effects of dietary soybean oil, animal tallow, sunflower oil or rapeseed oil on serum cholesterol. concentration were observed, irrespective of the level of dietary fat source used.

The fat content of thigh (Gastrocnemius): or breast (Pectoralis minor) muscle of poults, 16 weeks of age, was not 
appreciably altered by dietary animal tallow, soybean oil, sunflower oil or rapeseed oil.

Fatty acid composition and iodine number of carcass adipose tissue reflected that of the dietary fat, particularly when a $10 \%$ level of the fat source was used. 


\section{INTRODUCTION}

Nutritionally there has never been any reason to question the merit of fat as an ingredient in the food of man and animals. Fats are the richest sources of energy provided by animal or vegetable products. Weight for weight they supply 2.25 times as much energy as carbohydrate and. proteins.

Until recently, it was commonly believed that poultry had a low tolerance for fat. Therefore, no particular consideration was given to use fats as a feed supplement. About a decade ago a surplus of fats on the world market made fats economically feasible as a source of energy for poultry. This initiated intensive research on the use of fats in poultry rations.

Stimulation of chick growth by supplementing rations with various added dietary sources of fat has been demonstrated by many workers. However, little information is available concerning the influence of various dietary sources of fat on the performance of turkey poults.

The main objective of the research here reported was to compare the eifects of dietary soybean oil, sunflower oil, rapeseed oil and animal tallow on the performance of turkey poults. Growth rate, efficiency of feed utilization, metabolizable energy content of poult rations and fat 
deposition in the muscle tissues of the carcass were the primary criteria used in the study. Observations on related characteristics which might yield additional information on the effects of these fat sources were also made. 
RFVIEW OF LITERATURE

The supplementation of fat in the diet of growing chicks has been shown to have deleterious effects in some cases and beneficial effects in others. One of the first indications of the possible detrimental effect of excessive fat in chick rations was reported by Vermeuln (1932)。 Henderson et 2I (1940) showed that soybean oil was detrimental. to chick growth, when added at levels higher than 10 per cent. Yacowitz (1953) reported that whereas $21 / 2$ to 5 percent supplemental fat improved growth, higher levels, 10 to 25 percent, exerted an adverse influence on growth.

Scott et al (1947) reported that a high energy diet for growing chickens out performed rations of lower energy content. Siedier et al (1953) reported that chicks fed added. fat grew at a rate similar to that of the chicks fed a lowfat ration. Food and caloric efficiency data indicated that Pat added to the basal. ration at the 2 and 4 percent level was efficiently utilized but was not completely utilized when added at the 8 percent level.

Biely and March (1954) recognized that the response to supplemental fat was influenced by the composition of the basal diets. The addition of fat to low protein diets depressed growth rate and feed efficiency, whereas, the 
addition of fat to high protein diets stimulated growth and improved efficiency of feed utilization. With chicks, they found that the addition of 5 to 7.5 percent fat to a 19 percent protein diet depressed growth and feed efficiency, but when fat was added to a 24 percent protein diet, growth was unaffected or stimulated, and feed efficiency was improved. Broad Breasted Bronze poults consuming a 28 percent protein ration with added fat grew faster and utilized feed more efficiently than did poults consuming a diet containing only 20 percent protein and added fat. In both chick and poult rations, the addition of fat was advantageous when relatively high levels of protein were fed. These results were later confirmed by scott et al (1955) and waibel et al (1955). Donaldson et al (1955) and Leong et al (1955) reported that the ratio of the productive energy to the protein content in the ration affected growth rate and feed efficiency and that supplemental fat tended to impair growth by widening the calorie to protein ratio. Donaldson et al (1957) concluded. that the poor performance of high fat rations used in the past resulted primarily because of a failure to provide sufficient amino acids, and perhaps other essential nutrients, required in the higher energy rations.

Donaldson et al (1957) used chick starting rations containing up to 33.8 percent fat without depressing growth. 
In some cases, rations containing 30 percent fat actually supported more rapid growth than was obtained with rations containing lower levels of rat. Iess feed was required per unit of gain when fat was added. This is in agreement with the work of Combs et aI (1955 and 1956). The high fat ration $(33.8 \%)$ seemed to retard growth up to 3 weeks, apparently due to the physical bexture of the ration which interfered. with the feed consumption. After 3 weeks, nowever, the chicks grew normally.

Rand (1958) reported that, when chicks were fed isonitrogenous-isocaloric diets, the substitution of fat calories for glucose calories resulted in improved weight gains and greater protein and energy utilization. Highly significant improvements in growth were noted even though the calorie to protein ratios were constant.

\section{Soybean $0 i 1$}

Henderson et al (1940) fed soybean oil to White Leghorn chicks at levels of $0,2,4,8---22$ percent of the total ration. The mean weight of chicks at eight weeks of age did not vary significantly until fat reached the 10\% level, after which chick weight decreased progressively with each increment increase in fat content of the ration.

Sunde (1953) reported that early work indicated that sucrose increased the early growth rate of the chicks. In 
order to determine whether this stimulation was due to energy or to changes in the texture of the feed, soybean oil was substituted iso-calorically for 5 and 10 percent sucrose. These experiments failed to show that sucrose stimulated growth al though feed efficiency appeared to be improved. sligntly. Added soybean oil improved feed efficiency and stimulated growth. The latter results are in general agreement, with those of Slinger et al (1953); Yacowitz (1953) and Carver et al (1952)。

Dam et al (1959) supplemented chick diets with 7.5 percent soybean oil in such a way as to maintain a constant energy to protein ratio. Inclusion of soybean oil in the ration increased growth significantly and also improved feed efficiency. These workers also compared soybean oil, cottonseed oil, peanut oil, lard, hydrogenated cottonseed oil and corn oil for their growth promoting properties. Results obtained showed that all of the non-hydrogenated vegetable oils were approximately equally effective in promoting chick growth and improving feed efficiency, while the hydrogenated vegetable oil was much less effective. The growth differences between the nonhydrogenated vegetable oils and lard were also found to be significantly different. It appeared that the nutritional value of non-hydrogenated oil was markedly reduced in the process of hydrogenation. 
AnimaI Tallow

Schweigert et al (1953) reported an improvement in growth and feed utilization of chicks when 2 to 8 percent animal tallow was adaed to a low lat diet. Sunde (1954) fed chicks and turkey poults rations containing 2.2 to 5.0 percent white grease, prime tallow or soybean oil. He reported no consistent improvement in growth with chicks, but growth of turkey poults was slightly improved by feeding prime tallow in the ration. Feed conversion was improved when the various level of fats were fed to either chicks or turkey poults.

Aitken et al (1954) tested a broiler ration containing 10 percent beef tallow for its effect on growth rate, feed efficiency and carcass finish. Ten percent tallow in a high protein diet significantly increased growth rate and improved efficiency of feed utilization. These observations were confirmed by Yacowitz et aI (1954); Biely et al (1954 and 1957); Arscott (1958): Waibel et al (1955) Sunde (1956) and Sell and Hodgson (1962).

Donaldson et aI (1957) reported that the addition of 10\% stabilized animal. fat to chick rations, already containing approximately $4 \%$ fat, significantly improved growth and feed conversion through 4 weeks of age. Addition of $15 \%$ stabilized animal fat to a ration, already contajning $3.8 \%$ fat, resulted. 
in slightly greater gain and improved feed conversion through 7 weeks of age. When 22.5 or $30 \%$ fat was added to the latter ration, there was no improvement in growth, but less feed was required per unit of gain.

Waibel et al (1958) observed improved growth by turkeys when animal tallow was added to the diet at a level of 10\%, but only when protein levels were high. Menge et al (1961) reported that egg oil, corn oil, lard or soybean oil supplementation of the chick rations resulted in a highly significant increase in growth even when feed intake was equalized. No significant difference was noted between sources of fat. The observation that animal fat was equal to vegetable fat for growth promotion is not in agreement with the observation of Dam et al (1959). These workers reported that the growth response from supplementation with vegetable oil was significantly greater than that observed when lard was the fat source.

Rapeseed 0iI

Duel et al (1948) reported that growth rate of rats receiving dietary rapeseed oil was somewhat less and the efficiency of feed utilization poorer than when diets containing butter or cottonseed oil were fed. It was believed that the less efficient utilization of the rapeseed oil diet was due to poorer digestibility of the fat. 
Thomasson et al (1955) advanced a growth retardation theory in which the presence of "growth retarding" substance in specific fat sources was assumed. This theory has received support in the finding that erucic acid, which comprises 30 to $50 \%$ of the total fatty acids in rapeseed oil, may be responsible for the reduced growth rate of rats fed rations containing this oil.

Thomasson et aI (1955b) presented evidence that erucic acid is responsible for the growth inhioiting action of rapem seed oil. Their study involved two lines of experimentation. Firstly, the effect on growth of nasturtiumseed oil, which contained 80-90\% erucic acid, was compared with that of rapeseed oil which contained $40-57 \%$ of erucic acid. This experiment confirmed that the growth rate of the animals decreased as the erucic acid content of the diet increased. By interpolation, it appeared that 30 Calorie percent nasturtiumseed oil had the same effect on rate of growth as 57 Calorie percent of the rapeseed oil. The ratio between the 30 Calorie percent nasturtiumseed oil and 57 Calorie percent rapeseed oil $(1: 1.9)$ is nearly the same as the ratio illustrating the relative erucic acid content of the two oils. This study suggested the growth inhibiting action of rapeseed oil and nasturtiumseed oil was due to the presence of erucic acid. Further evidence was furnished by the second 
part of the investigation in which animals received tri-erucin and erucic acid mixed with ground nut oil and ground nut oil fatty acids, respectively. It appeared that growth on the mixture of ground nut oil and tri-erucin was the same as that when rapeseed oil was fed. Also growth on the mixture of ground nut oil fatty acids and erucic acid was the same as that on the rapeseed oil fatty acids. The addition of more erucic acid to rapeseed oil fatty acids depressed growth significanty as compared to the use of the normal rapeseed oil fatty acid mixture. These results indicated that the poor growth obtained with rapeseed oil was due to the presence of erucic acid。

Beare et al (1957) fed rats rapeseed oil and corn oil at $10 \%$ of the diet and observed no significant depression in weight gain. When rapeseed oil comprised $20 \%$ of the ration there was a significant reduction in weight gain. There was a linear decrease in growth rate as the level of dietary rapeseed oil increased above the 10\% level. As the level of dietary rapeseed oil increased, feed intake decreased. Since there was a significant difference in the amount of feed consumed, it was postulated that dietary rapeseed oil depressed appetite. These results were later confirmed by Beare et al (1958 and 1959).

Blakely et al (1960) fed Broad Breasted Bronze male 
turkeys at 20 to 24 . weeks of age all-mash inishing diets, with and without whole rapeseed as an energy source. The whole rapeseed supplied approximately $10 \%$ oil to the ration. A highly significant improvement in carcass finish and Iive weight gain $(P \leq 0.01)$ for those birds receiving the diet containing whole rapeseed was observed. These results with turkeys do not agree with those obtained when rats were the experimental animal. (Thomasson et al 1955: Beare et al 1957, 1958 and 1959; and Duel et al 1948).

Recently Sell and Hodgson (1962) compared rapeseed oil, soybean oil, sunflower oil and animal tallow as ingredients in broiler rations. They reported that at $4 \%$ of the ration, rapeseed oil and sunflower seed oil were as effective in promoting weight gains as $4 \%$ soybean oil, and were more effective than $4 \%$ animal tallow. All fat sources were similar in their growth stimulation properties when included in the ration at the $8 \%$ level. Tsang et al (1962) also reported that rapeseed oil had no detrimental effect on broiler performance. At the same time, feeds containing rapeseed oil were utilized as effectively as those containing stabilized yellow grease. These reports are also contradictory to the work previously reported with rats. 
Metabolizable Energy

It has been shown by Donaldson et al (1957) and Rand et al (1958) that the chick can utilize high level of fats as a source of energy. However there are significant differences between fats in the amount of energy which is available to the chick (Carver et al 1955; Sunde 1956; March et al (1957). The magnitude of this difference was quantitively demonstrated by Renner and Hill (1958) who determined the metabolizable energy value and apparent digestibility of a variety of fats ranging in iodine number from $44-169$.

Sibbald et al (1960 and 1961) reported that the available energy content of certain fats increased as the level of protein in the diet increased. The absorption of certain fatty acids by the chicks has been shown to be influenced by both unsaturated fatty acids and certain monoand triglycerides (Young and Renner 1960).

Sibbald et al (1961) reported that animal tallow contained significantly less metabolizable energy than either undegummed or degummed soybean oil. This is in agreement with the work of Sell and Hodgson (1962). Sibbald et al (1962) also reported that the addition of soybean oil to animal tallow did not improve the availability of the energy therein. 
Sell and Hodgson (1962) reported that rations containing soybean oil were higher in metabolizable energy than those containing sunflower oil, rapeseed oil and animal tallow. No significant difference between the metabolizable energy content of rations containing sunflower oil, rapeseed oil and animal tallow was observed.

Effect of Dietary Fat on Tissue Fat

The effect of dietary fat on the fat content of the chicken carcass has been studied by several investigators. Baldini and Rosenberg (1957) reported that an increase in the fat content of the diet without raising the calorie content of the diet did not increase deposition of body fat. Donaldson et al (1956) found that carcass fat increased as the calorie: protein ratio was increased. Leong et al (1959) reported that visceral fat deposition was affected more by source and amount of energy than by calorie; protein ratio. While these studies indicate that increasing the energy content of the diet would increase total carcass fat, they did not give information about the distribution of the fat in muscle tissues. Recent information on the deposition of dietary fat in the muscle of the chicken carcass was reported by Miller et al (1962). They pointed out that the addition of corn oil and lard at a level of $17.5 \%$ of the diet, significantly increased the fat content of the breast and thigh muscles. 
Sell and Hodgson (1962) reported that in general, fatty acid composition of the adipose tissue reflected that of the dietary fat, particularly when an $8 \%$ level of the fat source was fed.

Cruickshank (1934), Adams on et al (1961) and Rogler and Carrick (196I) reported that, on the basis of iodine number and degree of unsaturation, dietary fatty acias had a marked influence on carcass fat of chickens. Feigenbaum and Fisher (1959) also observed that the fatty acid composition of carcass fat was influenced by the composition of the dietary fat. The influence of rapeseed oil on body fat of fowl had been reported by Chomysn (1955). He observed that, after administering $40 \mathrm{ml}$ of rapeseed oil per day for 4 successive days, the subcutaneous and internal fat of young geese assumed the characteristics of rapeseed oil (iodine number, melting point and odor). 


\section{EXPERIMINTAL}

Male Broad Breasted Bronze poults obtained from a commercial hatchery were used in this study. At one day of age, the poults were wing-banded and distributed into the experimental lots on the basis of body weight to insure that the average starting weight. was equal for each experimental unit. The poults were placed in thermostaticallycontrolled, electrically-neated batteries equipped with wire floors'. Each experimental ration was assigned to 3 experimental pens according to a randomized block design. Each experimental pen contained 11 poults. The poults remained in these pens until 3 weeks of age, at which time they were transferred to broiler finishing batteries.

At 6 weeks of age, all poults on each of the 9 treatments were pooled together and were reassigned to 18 floor pens according to a complete randomized block design. Thus, each treatment was applied to two experimental pens. Weight gain and reed consumption data were recorded bi-weekly up to eight weeks of age and then every four weeks for the remainder of the experiment. The experiment was terminated when the poults were 16 weeks of age. Feed and water were supplied ad Iibitium. 
The ingredient composition of basal ration $A$ which was fed from 0 to 8 weeks of age is shown in the Table I. Each fat source was substituted in the basal ration for an equivalent weight of wheat and levels of wheat and soybean meal were adjusted to maintain a constant percentage of protein in the ration. Degummed soybean oill, crude sunflower oil, degummed rapeseed oil and stabilized animal tallow were included in the test rations at 5 and 10 percent of the total ration. Ration $B$, shown in Table $I$, was used as the basal ration from 8 to 16 weeks of age. Due to the grain price situation at the time, corn was chosen to replace wheat as a major energy source. In this case, the fat source was substituted in the basal ration for an equivalent weight of corn and levels of corn and soybean meal were aajusted to maintain a constant percentage of protein in the ration. To facilitate determination of metabolizable energy, total excrement was collected Irom each experimental pen for 3 consecutive days during the sixth week of experiment. Excreta collected were frozen immediately after collection. The frozen excreta were dried in an air convection oven at $70^{\circ} \mathrm{C}$. temperature. After drying the samples were ground and stored in sealed glass containers.

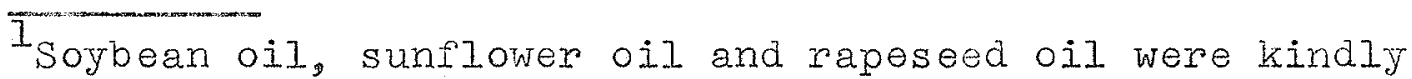
supplied by Co-operative Vegetable Oils Lta., Altona, Manitoba. 


\author{
TABIE I \\ COMPOSITION OF THE 29\% AND 21\% PROTIIN BASAL \\ STARTING AND GROWING RATION
}

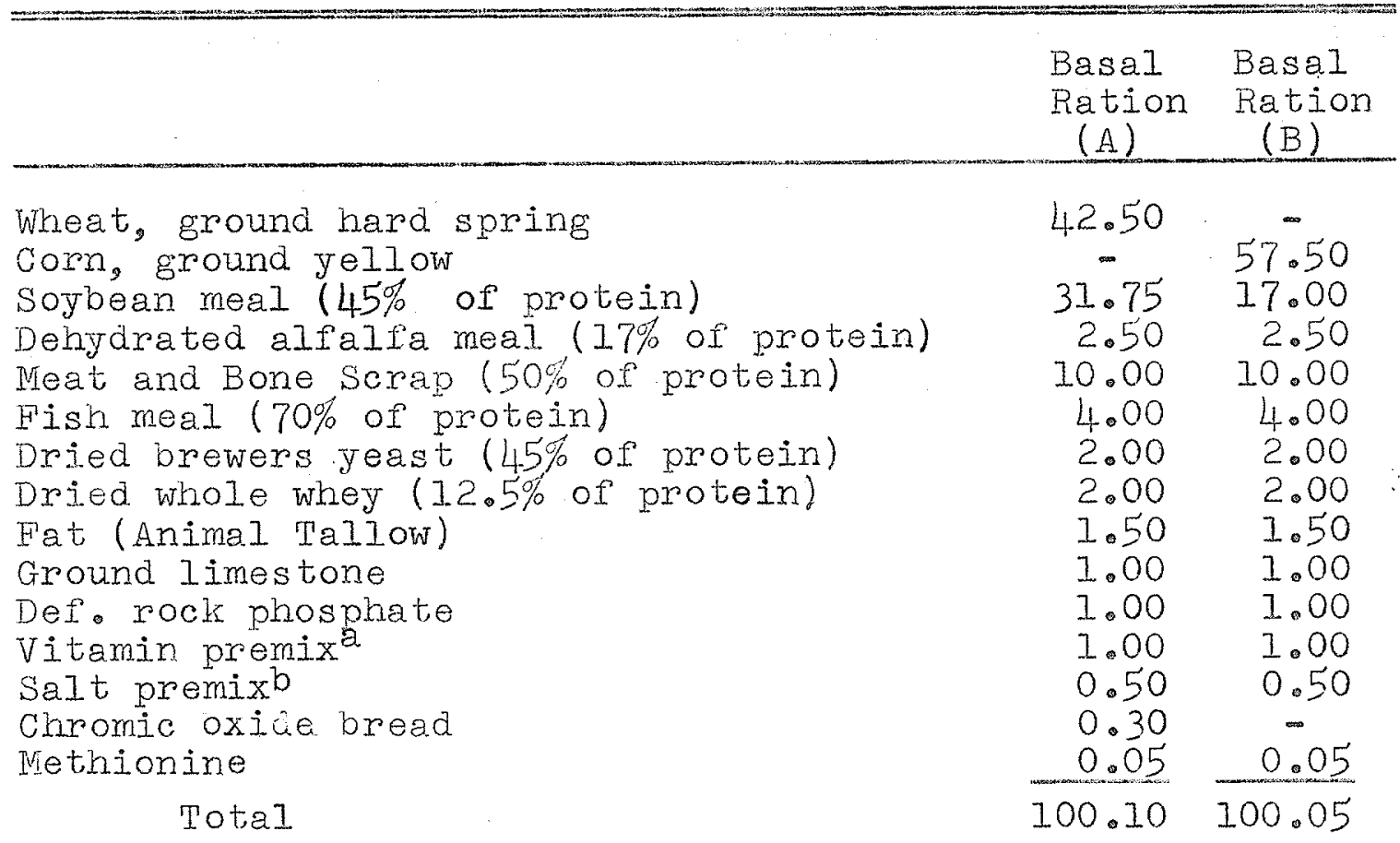

Calculated Analys is

$\begin{array}{lrr}\text { Protein }(\%) & 29.71 & 21.62 \\ \text { Fat }(\%) & 3.69 & 5.06 \\ \text { Crude fiber (\%) } & 4.31 & 3.52 \\ \text { Calcium }(\%) & 2.00 & 1.95 \\ \text { Phosphorous }(\%) & 1.20 & 1.07 \\ \text { Calories (productive energy)/1b. } & 805 & 946\end{array}$

a) Vitamin premix supplied the following per pound of ration: Vitamin A, 2750 I;U.Vitamin D $3,600 \mathrm{I} . \mathrm{C} . \mathrm{U}_{0}$; Vitamin E, 12.00 $\mathrm{mg}$ : Choline, $400.00 \mathrm{mg}$ : Vitamin $\mathrm{K}$ (Menadione), 1.00 mg.: Vitamin $B_{12}, 9$ mcg.; Riboflavin, $2.00 \mathrm{mg}$; Niacin, $30.00 \mathrm{mg}$; Pentothenic acid, $4.00 \mathrm{mg}$; Santoquin, $60.00 \mathrm{mg}$.

b) Salt and trace mineral mix supplied the following per pound of ration: Sodium chloride, 0.47\%; Zinc, $30.00 \mathrm{mg}$; Manganese, $50.00 \mathrm{mg}$; Iron, $6.00 \mathrm{mg}$. 
The procedure described by Hill and Anderson (1958) was used for the determination of metabolizable energy of the rations. Chromic oxide was used in the rations as an index substance to establish the ratio of excreta produced per unit of feed intake. Chromic oxide in the feed and excreta was determined by the method described by Czarnocki et al (1961). The heat of combustion of the feed and excreta was determined by the use of Parr Adiabatic calorimeter. Nitrogen in the feed and excreta was determined by the macrokjeldahl technique, described by the Association of Official Agricultural Chemists (1960). Metabolizable energy was calculated by this formula when:

$$
\begin{aligned}
& M_{0} E_{0}=A-\left[\begin{array}{lll}
B & x & \frac{C}{D}
\end{array}\right]-8.22\left[\begin{array}{lll}
E & -\left(\begin{array}{lll}
F & X & \frac{C}{D}
\end{array}\right]
\end{array}\right] \\
& \text { Where } \\
& \text { M. } \mathrm{H}_{0}=\text { Mietabolizable energy (Cal/g) } \\
& A=\text { Energy (gross) of feed ( } \mathrm{CaI} / \mathrm{g}) \\
& B=\text { Gross energy of dry excreta (CaI/g) } \\
& \mathrm{C}=\text { Chromic oxide content of feed (\%) } \\
& D=\text { Chromic oxide content of excrement (\%) } \\
& E=\text { Nitrogen/g of feed } \\
& \mathrm{F}=\mathrm{Nitrogen} / \mathrm{g} \text { of excrement }
\end{aligned}
$$

Blood samples were taken from three birds chosen randomly from each experimental pen. Blood samples were collected at 6,12 and 16 weeks of age from the wing vein. 
Coagulated blood samples were centrifuged, and the serum was removed and stored at $-10^{\circ} \mathrm{H}$. Serum cholesterol concentration was determined by the method described by zlatkis et al (1953).

At the end of 16 weeks, four randornly selected poults from each pen were killed and dressed. All the dressed carcasses were weighed and percent dressed weight was calculated. The carcasses were graded according to the Canada Department of Agriculture, Poultry grading standards.

Approximately 15 grams of abdominal adipose tissue were collected from two randomly selected carcasses from each pen. Fat was extracted from these samples according to the method described by the Association of official Agricultural Chemists (1960). Iodine numbers of these fat samples were measured by the Hanus method as described by Association of Dfficial Agricultural Chemists (1960)。 Quantitive analysis for fatty acia composition of the fat sources used in this investigation and the ether extract of carcass adipose tissue was accomplished by gas chromatography. A Burrell Model KD gas chromatograph was used and fatty acids (as methyl esters) were separated on a diethylene glycol succinate column with a flow rate of $120 \mathrm{ml}$. per minute and temperature of $198^{\circ} \mathrm{C}$.

Gastrocnemius and Pectoralis minor muscles were selected as representative of thigh and breast, muscles, respectively. These muscles were removed from two randomly selected carcasses 
representing each experimental pen. The muscles were ground in a meat grinder attachment of the Hobart ModeI K5-A and were then lyophilized. Fat content of the dried muscle tissue was determined by the method described by Association of oficial Agricultural Chemists (1960).

Data were subjected to analysis of variance (Snedecor, 1956) and multiple range comparisons were made according to Duncan (1955)。 


\section{RESULTS}

The original weight gain and efficiency of feed utilization data obtained when the poults were $2,4,6,8,12$ and 16 weeks of age and all analyses of variance are presented in Tables $1-13$ of the Appendix. The summary of weight gains at 4 weeks of age, presented in Table II, show that poults consuming rations containing 5 and $10 \%$ rapeseed oil gained significantly $(\mathrm{P}<0.05)$ Iess than poults on all other treatments. There were no significant $(P<0.05)$ differences in weight gains between the other treatments. Efficiency of feed utilization was significantly $(P<0.05)$ improved when poults were fed rations containing 5 or 10\% soybean o11, $10 \%$ animal tallow or 5 or 10\% sunflower oil. (Table III). Efficiency of feed utilization was not significantly improved by feeding rations containing $5 \%$ animal tallow or 5 and $10 \%$ rapeseed $0 i l$. Weight gain, feed efficiency and feed consumption data from 1 day to 6 weeks of age are given in Tables IV, $V$ and VI; respectively. The addition of rapeseed oil at levels of 5 and $10 \%$ of the ration significantly $(\mathrm{P}<0.05)$ reduced weight gains as compared to all other treatments. Poults receiving 5\% soybean oil gained significantly $(\mathrm{P}<0.05)$ more in body weight than poults consuming the basal ration. The inclusion of $5 \%$ sunflower oil and 5 or $10 \%$ animal tallow in the ration also appreciably improved weight gains compared to the basal ration. 
TABLE II

COMPARATIVE WFFETS OF DIETARY PATS ON WEIGHT GAIN OF TURKEYS FROM O TO 4 WEEKS OF AGE

\begin{tabular}{|c|c|c|c|c|c|c|c|c|c|}
\hline & $\begin{array}{l}10 \% \\
\text { Rape } \\
011\end{array}$ & $\begin{array}{l}5 \% \\
\text { Rape } \\
0 i 1\end{array}$ & $\begin{array}{l}10 \% \\
\text { Soybean } \\
011\end{array}$ & $\begin{array}{l}10 \% \\
\text { Sunflower }\end{array}$ & Basal & $\begin{array}{l}5 \% \\
\text { Animal } \\
\text { TaII ow }\end{array}$ & $\begin{array}{l}5 \% \\
\text { Sunflower } \\
\text { Oi] }\end{array}$ & $\begin{array}{l}10 \% \\
\text { Animal } \\
\text { Taliow }\end{array}$ & $\begin{array}{l}5 \% \\
\text { Soybean } \\
\text { OiI }\end{array}$ \\
\hline $\begin{array}{l}\text { Average } \\
\text { Weight } \\
\text { Gain } \\
\text { /poult }\end{array}$ & $(20)^{41}$ & $\begin{array}{l}427 \\
(14)\end{array}$ & $\begin{array}{l}517 \\
(10)\end{array}$ & $\begin{array}{l}522 \\
(13)\end{array}$ & $\begin{array}{l}526 \\
(26)\end{array}$ & $\begin{array}{l}528 \\
(27)\end{array}$ & $\begin{array}{l}541 \\
(23)\end{array}$ & $\begin{array}{l}543 \\
(10)\end{array}$ & $\begin{array}{l}563 \\
(7)\end{array}$ \\
\hline
\end{tabular}

$=0$

$a_{A 11}$ means not underscored by the same line are significantly different at $P<0.05$

Pigures in parentheses are standard errors. 
TABLE III

COMPARATIVE FFFECTS OF DIETARY FATS ON FFFICIENCY OF FEED UTILIZATION OF TURKEYS FROM O TO 4 WEEKS OF AGE

\begin{tabular}{|c|c|c|c|c|c|c|c|c|c|}
\hline & $\begin{array}{l}10 \% \\
\text { Soybean } \\
011\end{array}$ & $\begin{array}{l}10 \% \\
\text { Sunflower } \\
\text { Oil }\end{array}$ & $\begin{array}{l}5 \% \\
\text { Sunflower } \\
011\end{array}$ & $\begin{array}{l}5 \% \\
\text { Soybean } \\
\text { Oi1 }\end{array}$ & $\begin{array}{l}10 \% \\
\text { Animal } \\
\text { Tallow }\end{array}$ & $\begin{array}{l}\text { 10\% } \\
\text { Rape } \\
\text { OiI }\end{array}$ & $\begin{array}{l}5 \% \\
\text { Animal } \\
\text { Tallow }\end{array}$ & $\begin{array}{l}5 \% \\
\text { Rape } \\
011\end{array}$ & Basal. \\
\hline $\begin{array}{l}\text { Grams } \\
\text { of feed } \\
\text { Grams }\end{array}$ & $\frac{1.53^{a}}{(.01)^{b}}$ & $\begin{array}{l}1.55 \\
(.02)\end{array}$ & $\begin{array}{l}1.63 \\
(.00)\end{array}$ & $\begin{array}{l}1.65 \\
(.01)\end{array}$ & $\begin{array}{l}1.65 \\
(.07)\end{array}$ & $\begin{array}{l}1.77 \\
(.04) \\
\end{array}$ & $\begin{array}{l}1.77 \\
(.07)\end{array}$ & $\begin{array}{l}1.84 \\
(.04)\end{array}$ & $\begin{array}{l}1.84 \\
(.02)\end{array}$ \\
\hline
\end{tabular}

AII means not underscored by the same line are significantly different at $P<0.05$

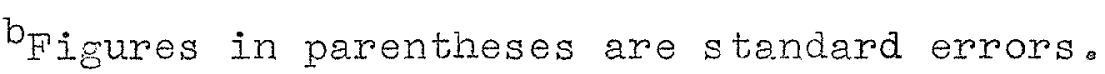


TABLE IV

COMPARATIVE EFFECTS OF DIETARY FATS ON WEIGHT GAIN OF TURIEYS FROM O TO 6 WEEKS OF AGE

\begin{tabular}{|c|c|c|c|c|c|c|c|c|c|}
\hline & $\begin{array}{l}\text { I0\% } \\
\text { Rape } \\
\text { OiI }\end{array}$ & $\begin{array}{l}5 \% \\
\text { Rape } \\
\text { OiI }\end{array}$ & Basal & $\begin{array}{l}10 \% \\
\text { Soybean } \\
\text { OiI }\end{array}$ & $\begin{array}{l}10 \% \\
\text { Sunflower } \\
0 \pm 1\end{array}$ & $\begin{array}{l}5 \% \\
\text { Sunflower } \\
0 i 1\end{array}$ & $\begin{array}{l}10 \% \\
\text { Animal } \\
\text { Tallow }\end{array}$ & $\begin{array}{l}5 \% \\
\text { Animal } \\
\text { Tal1 ow }\end{array}$ & $\begin{array}{l}5 \% \\
\text { Soybean } \\
0 i 1\end{array}$ \\
\hline $\begin{array}{l}\text { Average } \\
\text { Weight } \\
\text { Gain }\end{array}$ & $\frac{1046^{2}}{(32)^{b}}$ & $\begin{array}{l}1128 \\
(42)\end{array}$ & $\begin{array}{l}1251 \\
(41)\end{array}$ & $\begin{array}{l}1262 \\
(30)\end{array}$ & $\begin{array}{l}1277 \\
(39)\end{array}$ & $\begin{array}{l}1306 \\
(27) \\
\end{array}$ & $\begin{array}{l}1328 \\
(8)\end{array}$ & $\begin{array}{r}1338 \\
(36)\end{array}$ & $\begin{array}{l}1411 \\
(69)\end{array}$ \\
\hline
\end{tabular}

${ }^{2}$ AlI means not underscored by the same line are significantly different at, $P<0.05$

$b_{\text {Figures }}$ in parentheses are standard errors. 
TABLE $V$

COMPARATIVE EFPECTS OF DIETARY FATS ONEFEICIENCY OF FEED UTILTZATION OF TURKEYS FRON O TO 6 WEES OF AGE

\begin{tabular}{|c|c|c|c|c|c|c|c|c|c|}
\hline & $\begin{array}{l}10 \% \\
\text { Soybean } \\
0 i 1\end{array}$ & $\begin{array}{l}5 \% \\
\text { Sorbean } \\
0 i j\end{array}$ & $\begin{array}{l}10 \% \\
\text { Sunflower } \\
\text { Oil }\end{array}$ & $\begin{array}{l}5 \% \\
\text { Sunflower } \\
\text { oil }\end{array}$ & $\begin{array}{l}10 \% \\
\text { Animal } \\
\text { Tal1ow }\end{array}$ & $\begin{array}{l}10 \% \\
\text { Rape } \\
0 i 1\end{array}$ & $\begin{array}{l}5 \% \\
\text { AnimaI } \\
\text { TaIIow }\end{array}$ & $\begin{array}{l}5 \% \\
\text { Rape } \\
\text { OiI }\end{array}$ & Basal \\
\hline $\begin{array}{l}\text { Gram } \\
\text { Of feed }\end{array}$ & $\frac{1.60^{2}}{(.05)^{b}}$ & $\begin{array}{l}1.60 \\
(.09)\end{array}$ & $\begin{array}{l}1.60 \\
(.01)\end{array}$ & $\begin{array}{l}1.65 \\
(.03)\end{array}$ & $\begin{array}{l}1.66 \\
(.04)\end{array}$ & $\begin{array}{l}1.70 \\
(.01)\end{array}$ & $\begin{array}{l}1.75 \\
(.07) \\
\end{array}$ & $\begin{array}{l}1.84 \\
(.02) \\
\end{array}$ & $\begin{array}{l}1.87 \\
(.05)\end{array}$ \\
\hline
\end{tabular}

$a_{A 11}$ means not underscored by the same line are significantly different at $P<0.05$

Figures in parentheses are standard errors. 
TABLE VI

COMPARATIVE EFEECTS OF DIETARY FATS ON FEFD CONSUMPTION OF TURKEYS FROM O TO 6 WEERS OF AGE

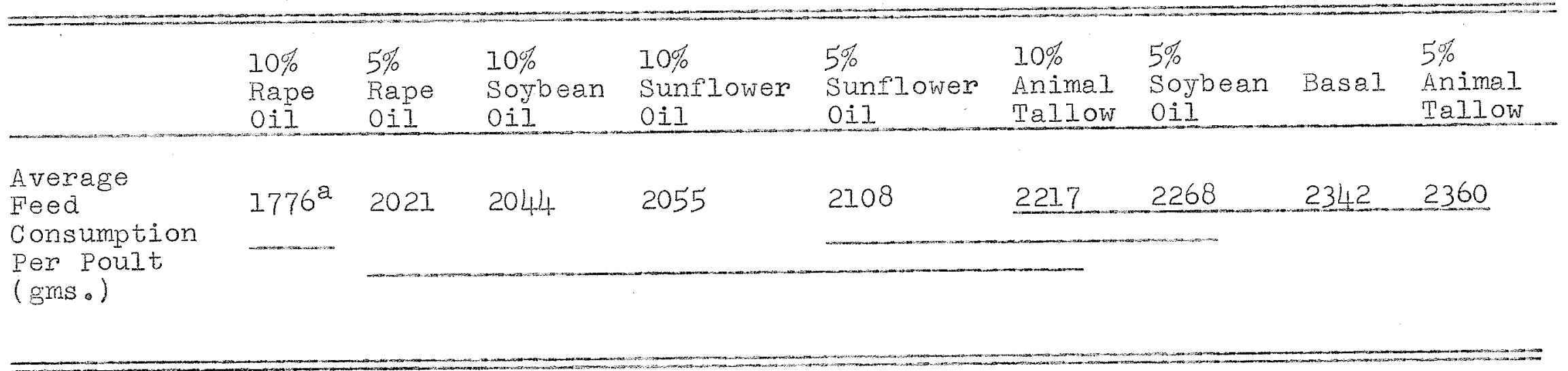

${ }^{2}$ All means not underscored by the same line are significantly different at $P<0.05$ 
but this improvement was not significant $(P<0.05)$. Efficiency of feed utilization was improved by all fat additions. However, significant $(P<0.05)$ improvements in feed utilization were observed only when 5 and $10 \%$ soybean oil, 5 and 10\% sunflower oil, $10 \%$ animal tallow or $10 \%$ rapeseed oil were added to the ration. In general, the inclusion of a fat source in the ration caused a decrease in feed consumption. Poults fed rations containing 5\% rapeseed oil, $5 \%$ sunflower oil, 10\% sunflower oil or 10\% soybean oil consumed significantly lessfeed than basal-fed poults while poults fed the $10 \%$ rapeseed oil ration consumed significantly less feed than poults on all other treatments. Weight gain and efficiency of feed utilization data from 1 day to 12 weeks of age are show in Tables VII and VIII, respectively. Feeding 5 and $10 \%$ rapeseed oil in the ration continued to significantly $(P<0.05)$ reduce weight gains. Including five percent animal tallow and 5\% soybean oil in the ration improved weight gains as compared to the basal ration, but the improvement was not significant $(\mathrm{P}<0.05)$. Including five and $10 \%$ sunflower 0 il, $10 \%$ soybean oil and 10\% animal tallow in the ration did not improve weight gains as compared to gains of poults fed the basal ration. Efficiency of feed utilization was improved by all fat additions. Significant $(P<0.05)$ improvement in 
TABLF VII

COMPARATIVE EFEETS OF DIETARY FATS ON WEIGET GAIN OF TURKEY FROM O TO 12 WEEKS OF AGE

\begin{tabular}{|c|c|c|c|c|c|c|c|c|c|}
\hline & $\begin{array}{l}10 \% \\
\text { Rape } \\
\text { Oi1 }\end{array}$ & $\begin{array}{l}5 \% \\
\text { Rape } \\
011\end{array}$ & $\begin{array}{l}10 \% \\
\text { Soy'oean } \\
\text { Oil }\end{array}$ & $\begin{array}{l}10 \% \\
\text { Sunfin ower } \\
0 i 1\end{array}$ & $\begin{array}{l}5 \% \\
\text { Sunflower } \\
\text { oil }\end{array}$ & $\begin{array}{l}10 \% \\
\text { Animal } \\
\text { Taliow }\end{array}$ & Basa] & $\begin{array}{l}5 \% \\
\text { Soybean } \\
\text { OiI }\end{array}$ & $\begin{array}{l}5 \% \\
\text { Animal } \\
\text { Tal1ow }\end{array}$ \\
\hline $\begin{array}{l}\text { Average } \\
\text { Weight } \\
\text { Gain }\end{array}$ & $\begin{array}{l}8.40^{a} \\
(.20)^{b}\end{array}$ & $\begin{array}{l}8.85 \\
(.15)\end{array}$ & $\begin{array}{l}9.55 \\
(.05)\end{array}$ & $\begin{array}{l}9.60 \\
(.20)\end{array}$ & $\begin{array}{l}9.65) \\
(.15)\end{array}$ & $\begin{array}{l}9.75 \\
(.15) \\
\end{array}$ & $\begin{array}{l}9.80 \\
(.20) \\
\end{array}$ & $\begin{array}{l}9.85 \\
(.15)\end{array}$ & $\begin{array}{l}10.30 \\
(.20) \\
\end{array}$ \\
\hline
\end{tabular}

${ }_{A}^{A} I$ means not underscored by the same line are significantly aifferent at $P<0.05$

Figures in parentheses are standard errors. 
TABLE VIII

COMPARATIVE FFFECTS OF DIETARY FATS ON EFFICIENCY OP FEED UTIIIZATION OF TURKEYS FROM O TO 12 WEERS OF AGE

\begin{tabular}{|c|c|c|c|c|c|c|c|c|c|}
\hline & $\begin{array}{l}10 \% \\
\text { Soybean } \\
\text { OiI }\end{array}$ & $\begin{array}{l}5 \% \\
\text { Animal } \\
\text { Tallow }\end{array}$ & $\begin{array}{l}10 \% \\
\text { Rape } \\
\text { Oil }\end{array}$ & $\begin{array}{l}\text { I0\% } \\
\text { Animal } \\
\text { Tallow }\end{array}$ & $\begin{array}{l}10 \% \\
\text { Sunflower } \\
\text { Oil }\end{array}$ & $\begin{array}{l}5 \% \\
\text { Rape } \\
0 i 1\end{array}$ & $\begin{array}{l}5 \% \\
\text { Soybean } \\
\text { Oi1 }\end{array}$ & $\begin{array}{l}5 \% \\
\text { Sunflower } \\
\text { Oil }\end{array}$ & Basal \\
\hline $\begin{array}{l}\text { Pounds } \\
\text { of feed } \\
\text { Pounds } \\
\text { of gain }\end{array}$ & ${ }^{2.1} .12^{a}$ & $\begin{array}{l}2.14 \\
(.10)\end{array}$ & $\begin{array}{l}2.18 \\
(.05)\end{array}$ & $\begin{array}{l}2.21 \\
(.02)\end{array}$ & $\begin{array}{l}2.24 \\
(.07)\end{array}$ & $\begin{array}{l}2.34 \\
(.02) \\
\end{array}$ & $\begin{array}{l}2.34 \\
(.01) \\
\end{array}$ & $\begin{array}{l}2.38 \\
(.05) \\
\end{array}$ & $\begin{array}{l}2.47 \\
(.03)\end{array}$ \\
\hline
\end{tabular}

$-2$

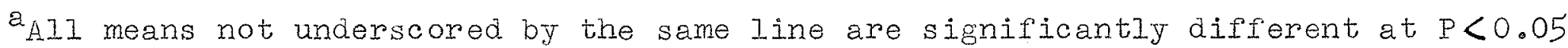

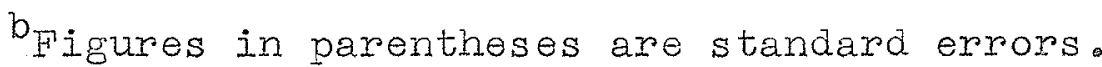


the efficiency of feed utilization was obtained by adding $10 \%$ soybean oil, 5 or 10\% animal tallow, $10 \%$ rapeseed ojl and $10 \%$ sunflower oil to the ration. However, efficiency of feed utilization was not significantly $(\mathrm{P}<0.05)$ improved by feeding rations containing $5 \%$ sunflower oil, $5 \%$ soybean oil or 5\% rapeseed oil. Rations containing 10\% soybean oil or $10 \%$ rapeseed oil significantly $(\mathrm{P}<0.05)$ improved the efficiency of peed utilization as compared to rations containing $5 \%$ level of the same fat sources. Weight gain, efficiency of feed utilization and feed consumption data from 1 day to 16 weeks of age are given in Tables IX, $X$ and XI respectively. Poults fed $10 \%$ rapeseed oil continued to gain significantly $(P<0.05)$ less weight than poults fed the basal ration. weight gains were slightly depressed when rations containing $5 \%$ rapeseed oil or $10 \%$ soybean oil were fed as compared to the basal ration, but tilis depression was not significant. Feeding rations containing $5 \%$ or $10 \%$ animal tallow, $5 \%$ or $10 \%$ sunflower oil or $5 \%$ soybean oil improved weight gains slightly but not significantly $(P<0.05)$. Efficiency of feed utilization was significantly $(\mathrm{P}<0.05)$ jmproved by all fat aditions. Feeding $10 \%$ soybean oil in the ration significantIy $\left(P<0.05^{\prime}\right)$ improved the efficiency of feed utilization as compared to all other ration treatments except when the ration containing $10 \%$ rapeseed oil was fed. 
TABLE IX

COMPARATIVE EFFECTS OF DIETARY FATS ON WEIGHT GAIN OF TURKEYS FROM O TO 16 WEEKS OF AGE

\begin{tabular}{|c|c|c|c|c|c|c|c|c|c|}
\hline & $\begin{array}{l}10 \% \\
\text { Rape } \\
\text { Oi1 }\end{array}$ & $\begin{array}{l}5 \% \\
\text { Rape } \\
\text { OiI }\end{array}$ & $\begin{array}{l}10 \% \\
\text { Soybean } \\
011\end{array}$ & Basal & $\begin{array}{l}5 \% \\
\text { Sunflower } \\
\text { Oil }\end{array}$ & $\begin{array}{l}10 \% \\
\text { Sunflower } \\
\text { Oil }\end{array}$ & $\begin{array}{l}5 \% \\
\text { Soybean } \\
\text { OiI }\end{array}$ & $\begin{array}{l}5 \% \\
\text { Animal } \\
\text { Tallow }\end{array}$ & $\begin{array}{l}10 \% \\
\text { Animal } \\
\text { Tallow }\end{array}$ \\
\hline $\begin{array}{l}\text { Average } \\
\text { Weight } \\
\text { Gain }\end{array}$ & $\frac{13.80^{a}}{(.20)^{b}}$ & $\begin{array}{l}14.25 \\
(.15)\end{array}$ & $\begin{array}{l}14.80 \\
(.20) \\
\end{array}$ & $\begin{array}{l}14.85 \\
(.15) \\
\end{array}$ & $\begin{array}{r}15.15 \\
(.25) \\
\end{array}$ & $\begin{array}{r}15.25 \\
(.15) \\
\end{array}$ & $\begin{array}{r}15.25 \\
(.15) \\
\end{array}$ & $\begin{array}{r}75.40 \\
(.50) \\
\end{array}$ & $\begin{array}{l}15.40 \\
(.20) \\
\end{array}$ \\
\hline
\end{tabular}

all means not underscored by the same line are significantly different at $P<0.05$

bigures in parentheses are standard errors. 


\section{TABLE X}

CONPARATIVE EFEECTS OF DIETARY FATS ON EFFICIENCY OF FEED UTILIZATION

OF TURKEYS FROM O TO 16 WEEKS OF AGE

\begin{tabular}{|c|c|c|c|c|c|c|c|c|c|}
\hline & $\begin{array}{l}10 \% \\
\text { Soybean } \\
\text { oil }\end{array}$ & $\begin{array}{l}10 \% \\
\text { Rape } \\
\text { OiI }\end{array}$ & $\begin{array}{l}10 \% \\
\text { Sunflower } \\
0 \pm 1\end{array}$ & $\begin{array}{l}10 \% \\
\text { Animal } \\
\text { Taliow }\end{array}$ & $\begin{array}{l}5 \% \\
\text { Animal } \\
\text { Tallow }\end{array}$ & $\begin{array}{l}5 \% \\
\text { Rape } \\
\text { OiI }\end{array}$ & $\begin{array}{l}5 \% \\
\text { Sunf I ower } \\
\text { Oil }\end{array}$ & $\begin{array}{l}5 \% \\
\text { Soybean } \\
\text { OiI }\end{array}$ & Basal \\
\hline $\begin{array}{l}\text { Pounds of } \\
\text { feed } \\
\text { Pounds of }\end{array}$ & $\begin{array}{l}2.45^{a} \\
(.02)^{b}\end{array}$ & $\begin{array}{l}2.55 \\
(.07)\end{array}$ & $\begin{array}{l}2.69 \\
(.02) \\
\end{array}$ & $\begin{array}{l}2.69 \\
(.03) \\
\end{array}$ & $\begin{array}{l}2.69 \\
(.08) \\
\end{array}$ & $\begin{array}{l}2.74 \\
(.06) \\
\end{array}$ & $\begin{array}{l}2.77 \\
(.07) \\
\end{array}$ & $\begin{array}{l}2.80 \\
(.05) \\
\end{array}$ & $\begin{array}{l}3.01 \\
(.06) \\
\end{array}$ \\
\hline
\end{tabular}

$a_{A I I}$ means not underscored by the same line are significantly different at $P<0.05$

Figures in parentheses are standard errors. 
TABIS XI

COMPARATIVE EFFECTS OF DIETARY FATS ON FEED CONSUNPTION OF TURKEYS FROM O TO 16 WEERS OF $A G E$

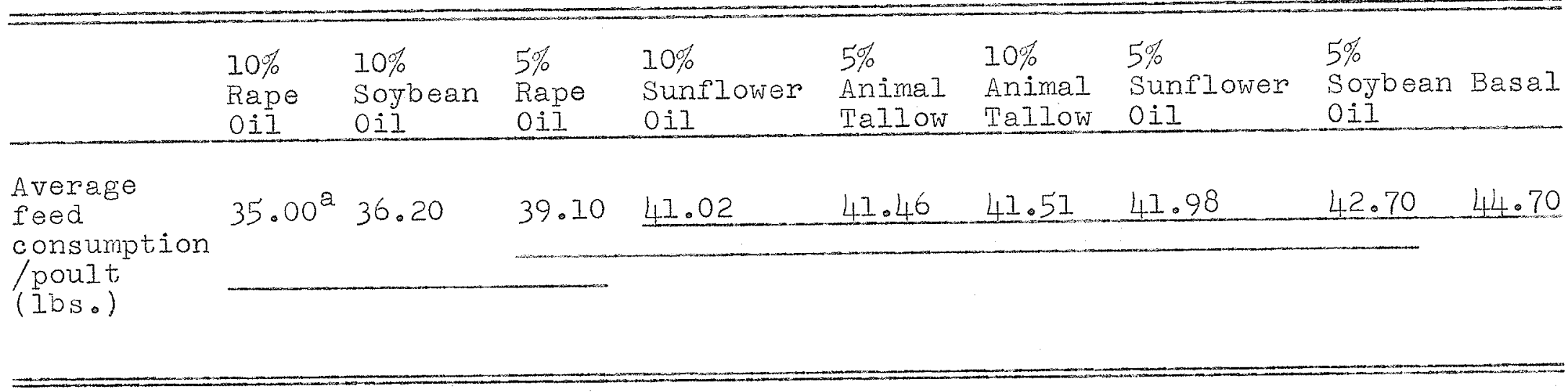

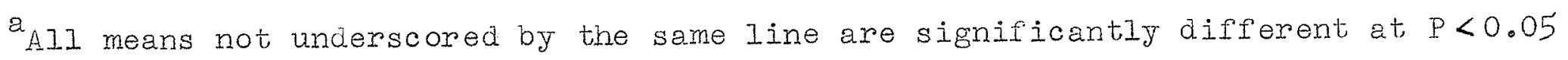


Poults fed $5 \%$ rapeseed oil, $10 \%$ rapeseed oil or $10 \%$ soybean oil consumed significantly less feed than poults fed the basal ration.

\section{Figure 1 , illustrates the influence of various fat} sources on weight gain of poults at 4,6,8,12 and 16 weeks of age when included in the ration at a 10\% level. The growth depressing effect of $10 \%$ rapeseed oil was apparent when the poults were 4 weeks of age and became increasingly evident with time on treatment. Addition of $10 \%$ animal tallow and $10 \%$ sunflower oil to the ration markedly improved weight gains of poults through 16 weeks of age although the improvement was not apparent until after 12 weeks of age. The data on metabolizable energy of the rations are shown in the Table XII. When used as $5 \%$ of the ration, rapeseed oil, animal tallow and soybean oil were quite similar with respect to resulting ration metabolizable energy values. The ration containing $5 \%$ sunflower oil had a metabolizable energy value significantly $(P<0.05)$ higher than rations containing $5 \%$ rapeseed oil, aniral tallow or soybean oil. However, very close similarity between animal tallow, soybean oil and sunflower oil was observed when the fat sources comprised $10 \%$ of the ration. The ration containing 10\% rapeseed oil was significantly higher in metabolizable energy than rations containing 10\% animal tallow, soybean oil 


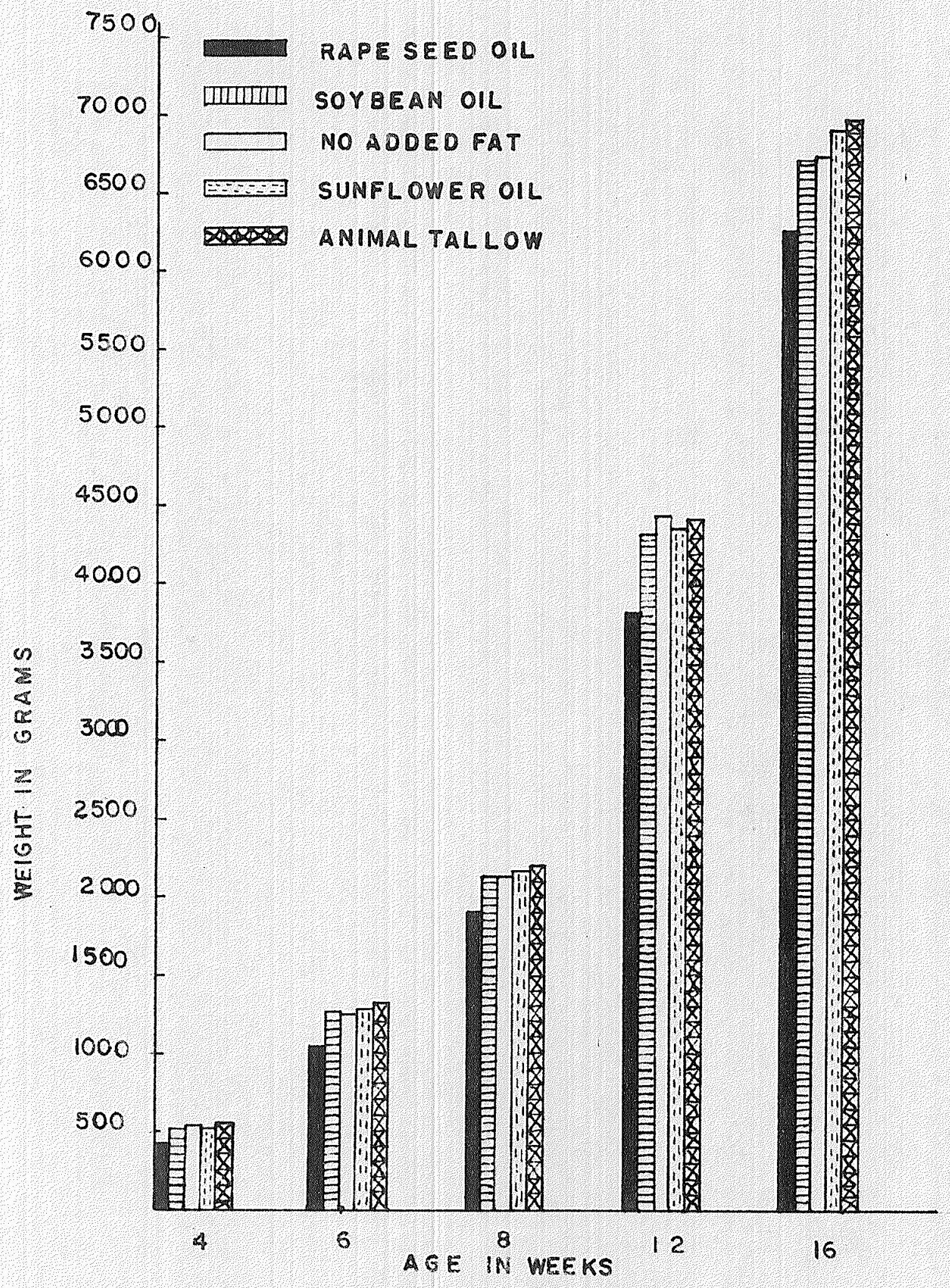

FIGURE I

COHPARATIVE EFFECTS OF FATS ON WEIGHT GAIN WHEN FED AS 10 PERCENT OF THE RATION. 


\section{TABLE XII}

NETABOLIZABIE ENERGY AND NITROGEN RETENTION OF RATIONS CONTAINING DIFEERENT FAT SOURCES AS DETERMINED WITH TURKGY POULTS FROM 5 TO 6 WEEKS OF AGE

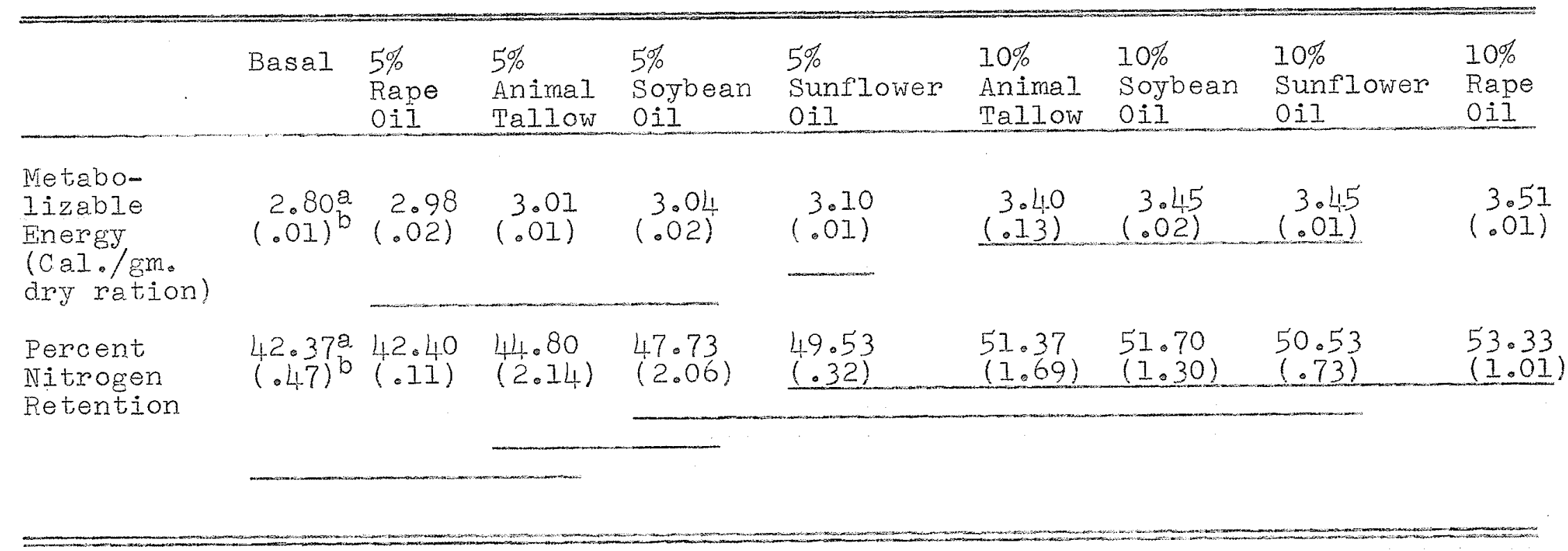

AII means not underscored by the same line are significantly different at $P<0.05$

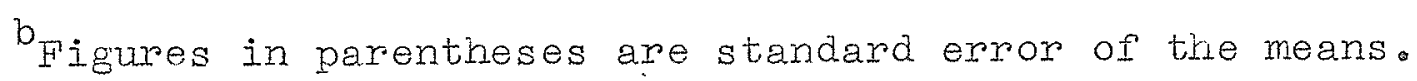


or sunflower oil. These data indicate that energy supplied by a retion containing $10 \%$ rapeseed oil was as available to the poults as energy derived from comparable levels of dietary animal tallow, soybean oil and sunflower oil. Thus it appears that the growth depressing factor in rapeseed oil is not directly related to energy availability.

The data concerning the percentage of dietary nitrogen retained by poults consuming the various sources of fats is also given in Table XII. Compared to the basal ration, only the ration containing $5 \%$ rapeseed oil or $5 \%$ animal tallow failed to significantly increase nitrogen retention. Nitrogen retention by poults consuming rations containing soybean oil and sunflower oil at either the 5 or $10 \%$ level was not significantly difierent. However, nitrogen retention was significantly increased when anjmal tallow or rapeseed oil was included in the ration at the $10 \%$ level rather than at the $5 \%$ level.

At 6,12 and 16 weeks of age, the various dietary sources of fat had no significant effect on the blood serum cholesterol concentration, irrespective of level of fat used (Table XIII)。

The dressing percentages and carcass grades of poults receiving various sources and levels of dietary fats are given in Table XIV. There were no significant differences 
TABIE XIII

EFFECT OF ADDED DIBTARY FATS ON BLOOD SERUV CHOLESTEROL LEVELS OF TURKEYS

\begin{tabular}{|c|c|c|c|c|c|}
\hline $\begin{array}{l}\text { Ration } \\
\text { Preatment } \\
\end{array}$ & $\begin{array}{l}6 \text { Weeks } \\
\text { of age }\end{array}$ & & $\begin{array}{l}12 \text { weeks } \\
\text { of age }\end{array}$ & $\begin{array}{l}16 \text { weeks } \\
\text { of age }\end{array}$ & \\
\hline & $m g \cdot 1100$ & $m]=$ & $\mathrm{mg} . / 100 \mathrm{ml}$ & $m g \cdot / 100$ & m. \\
\hline Basal & 179.72 & $\pm 16.9^{b}$ & $166.24^{a} \pm 0.4^{b}$ & $155 \cdot 22^{2}$ & $\pm 6.0^{b}$ \\
\hline $\begin{array}{ll}\text { Soybean oil, } & 5 \% \\
\text { Soybean oil, } & 10 \%\end{array}$ & $\begin{array}{l}189.99 \\
212.49\end{array}$ & $\begin{array}{l} \pm 10.9 \\
\pm 12.4\end{array}$ & $\begin{array}{l}178.70 \pm 18.7 \\
173.75 \pm 21.2\end{array}$ & $\begin{array}{l}149.58 \\
163.33\end{array}$ & $\begin{array}{l} \pm 5 \cdot 4 \\
\pm 8 \cdot 3\end{array}$ \\
\hline $\begin{array}{ll}\text { Sunflower oil, } & 5 \% \\
\text { Sunflower oil, } & 10 \%\end{array}$ & $\begin{array}{l}182.77 \\
212.91\end{array}$ & $\begin{array}{l} \pm 15.9 \\
\pm 10.9\end{array}$ & $\begin{array}{l}159.16 \pm 5.8 \\
186.04 \pm 7.7\end{array}$ & $\begin{array}{l}150.83 \\
160.83\end{array}$ & $\begin{array}{l} \pm 2.5 \\
\pm 11.7\end{array}$ \\
\hline $\begin{array}{l}\text { Rapeseed oil, } 5 \% \\
\text { Rapeseed oil, } 10 \%\end{array}$ & $\begin{array}{l}214 \cdot 16 \\
227 \cdot 33\end{array}$ & \pm 12.1 & $\begin{array}{l}170.41 \pm 9.6 \\
166.16 \pm 7.8\end{array}$ & $\begin{array}{l}162.49 \\
169.16\end{array}$ & $\begin{array}{l} \pm 5.7 \\
\pm 2.5\end{array}$ \\
\hline $\begin{array}{ll}\text { Animal tallow, } 5 \% \\
\text { Animal tallow, } 10 \%\end{array}$ & $\begin{array}{l}197.94 \\
191.22\end{array}$ & $\pm 11 \cdot 3$ & $\begin{array}{r}183.33 \pm 18.3 \\
193.33 \pm 9.9\end{array}$ & $\begin{array}{l}155 \cdot 41 \\
158 \cdot 74\end{array}$ & $\begin{array}{l} \pm 3.7 \\
\pm 0.4\end{array}$ \\
\hline
\end{tabular}

a No significant differences at $\mathrm{P}=0.05$ or less.

Figures preceeded by \pm sign are standard errors. 
TABLE XIV

DRESSING PERCENT AND CARCASS GRADES OF 16 WEERS OLD TURKEY POULTS

\begin{tabular}{lll}
\hline $\begin{array}{l}\text { Ration } \\
\text { Treatment }\end{array}$ & Mean dressing percent & Meancarcass scores \\
\hline Basal & $76.23 \pm 0.1^{b}$ & $87.50 \pm 2.5^{b}$ \\
Soybean oil, 5\% & $78.71 \pm 1.3$ & $87.50 \pm 2.5$ \\
Soybean oil, 10\% & $76.95 \pm 0.2$ & $88.75 \pm 1.2$ \\
Sunflower oil, 5\% & $77.20 \pm 0.5$ & $82.50 \pm 2.5$ \\
Sunflower oil, 10\% & $74.61 \pm 0.05$ & $86.25 \pm 1.2$ \\
Rapeseed oil, 5\% & $77.91 \pm 0.8$ & $87.50 \pm$ \\
Rapeseed oil, $10 \%$ & $77.96 \pm 0.9$ & $90.00 \pm 2.5$ \\
Animal tallow, 5\% & $75.65 \pm 0.6$ & $86.25 \pm 3.7$ \\
Animal tallow, 10\% & $78.16 \pm 1.8$ & $90.00 \pm 2.5$ \\
\end{tabular}

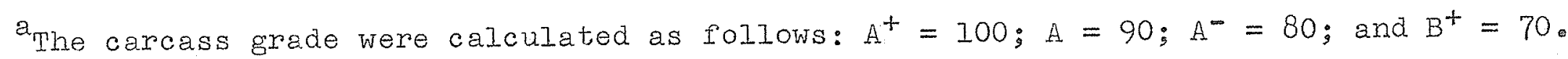

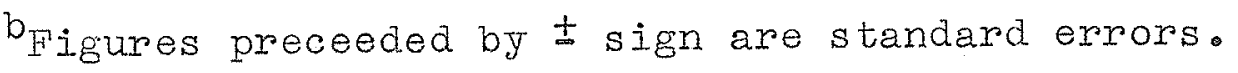


between ration treatments with respect to dressing percent and carcass grades.

Effect of added dietary fat on tissue fat and on the iodine numbers of abdominal adipose tissue are shown in Table XI. Sources or levels of dietary fat had no significant effect on the percent fat present in the Pectoralis minor and Gastrocnemius muscles. The iodine number of adipose tissue taken from poults at 16 weeks of age generally reflected that of the dietary fat. The iodine number of tissues from poults consuming animal tallow was significantly lower than that of tissue from poults fed the basal ration. In contrast, feeding vegetable oils caused a significant increase in iodine number. The fact that the iodine number of adipose tissue of poults receiving a particular vegetable oil at the $10 \%$ level were significantly higher than that of poults receiving only $5 \%$ of the same oil, illustrates the marked effect that the type and level of dietary fat had on carcass fat. Fatty acid composition of fat sources used in rations and abdominal adipose tissue of 16 weeks old turkey poults is shown in Table XVI. The data presented show that in comparison with the adipose tissue of poults receiving the basal ration, adipose tissue of poults receiving animal tallow reflected the relatively high stearic and oleic acid $\left(\mathrm{C}_{18}\right.$ and $\left.\mathrm{C}_{18: 1}\right)$ content and the low linoleic acid and linolenic 
TABLE XV

EFEECT OF ADDED DIETARY FAT2 ON TISSUE FAT AND ON THE IODINE VALUES OF ABDONINAL ADIPOSE TISSUE OF 16 WEEK-OLD TURKEYS

\begin{tabular}{|c|c|c|c|c|c|c|c|c|c|}
\hline $\begin{array}{l}\text { Ration } \\
\text { Treatments }\end{array}$ & $\begin{array}{l}5 \% \\
\text { Animal } \\
\text { Tallow }\end{array}$ & $\begin{array}{l}10 \% \\
\text { Animal } \\
\text { Tallow }\end{array}$ & Basal & $\begin{array}{l}5 \% \\
\text { Rape } \\
011 \\
\end{array}$ & $\begin{array}{l}10 \% \\
\text { Rape } \\
\text { OiI }\end{array}$ & $\begin{array}{l}5 \% \\
\text { Sunflower } \\
011\end{array}$ & $\begin{array}{l}5 \% \\
\text { Soybean } \\
\text { Oil } \\
\end{array}$ & $\begin{array}{l}10 \% \\
\text { Soybean } \\
011\end{array}$ & $\begin{array}{l}10 \% \\
\text { Sunflower } \\
\text { Oil }\end{array}$ \\
\hline $\begin{array}{l}\text { Gastrocanemious } \\
\text { muscle, \% fat } \\
\text { (Miean) }\end{array}$ & $\begin{array}{l}5.13^{b} \\
(.71)^{c}\end{array}$ & $\begin{array}{l}5.02 \\
(.47) \\
\end{array}$ & $\begin{array}{r}4.66 \\
(.85) \\
\end{array}$ & $\begin{array}{r}4.83 \\
(.63) \\
\end{array}$ & $\begin{array}{l}5.53 \\
(.14) \\
\end{array}$ & $\begin{array}{l}5.50 \\
(.84) \\
\end{array}$ & $\begin{array}{l}5.18 \\
(.66) \\
\end{array}$ & $\begin{array}{l}3.59 \\
(.46) \\
\end{array}$ & $\begin{array}{r}4.94 \\
(.40) \\
\end{array}$ \\
\hline $\begin{array}{l}\text { Pectorazis } \\
\text { minor muscle, } \\
\text { \% Fat (Niean) }\end{array}$ & $\begin{array}{l}2.55^{b} \\
(.62)^{c} \\
\end{array}$ & $\begin{array}{l}3.28 \\
(\cdot 27) \\
\end{array}$ & $\begin{array}{l}2.48 \\
(.25) \\
\end{array}$ & $\begin{array}{l}2.40 \\
(.58) \\
\end{array}$ & $\begin{array}{l}2.70 \\
(.77) \\
\end{array}$ & $\begin{array}{l}2.68 \\
(.02) \\
\end{array}$ & $\begin{array}{l}1.99 \\
(.12) \\
\end{array}$ & $\begin{array}{l}2.19 \\
(.17) \\
\end{array}$ & $\begin{array}{l}2.47 \\
(.05) \\
\end{array}$ \\
\hline $\begin{array}{l}\text { Mean Iodine } \\
\text { Numbers }\end{array}$ & $\begin{array}{r}69.7^{b} \\
(.10)^{c}\end{array}$ & $\begin{array}{l}71.4 \\
(.50)\end{array}$ & $\begin{array}{l}76.8 \\
(.70)\end{array}$ & $\begin{array}{l}92.5 \\
(.60)\end{array}$ & $\begin{array}{l}97.5 \\
(.10)\end{array}$ & $\frac{105.1}{(3.45)}$ & $\frac{108.0}{(.90)}$ & $\begin{array}{l}113.7 \\
(.10)\end{array}$ & $\begin{array}{l}118.0 \\
(.50)\end{array}$ \\
\hline
\end{tabular}

a Dietary fat sources had the following iodine numbers; animal tallow 51.87; rapeseed oil 115.25 ; soybean oil 134.78; and sunflower oil 140.70.

bAll means not, underscored by the same line are significantly different at $P<0.05$

Figures in parentheses are standard errors. 
TABIE XVI

FATTY ACID COMPOSITION OF FAT SOURCES USED IN RATIONS AND ABDOMINAT ADIPOSE TISSUE

OF I6-WEEK OLD TURKEY POULTS

\begin{tabular}{|c|c|c|c|c|c|c|c|c|c|}
\hline & $\mathrm{C}_{14}$ & $\mathrm{C}_{16}$ & $\mathrm{C}_{16: 1}$ & $\mathrm{C}_{18}$ & $\mathrm{C}_{18: 1}$ & $\mathrm{C}_{18: 2}$ & $\mathrm{C}_{18: 3}$ & $\mathrm{C}_{20: 1}$ & $C_{22: 1}$ \\
\hline \multicolumn{10}{|c|}{ Fat source added to ration } \\
\hline $\begin{array}{l}\text { Animal tallow } \\
\text { Soybean oil } \\
\text { Sunilower seed oil } \\
\text { Rapeseed oil }\end{array}$ & $\begin{array}{l}3.12 \\
= \\
-\end{array}$ & $\begin{array}{r}30.63 \\
10.72 \\
7.88 \\
3.87\end{array}$ & $\begin{array}{l}4 \cdot 26 \\
- \\
= \\
=\end{array}$ & $\begin{array}{r}19.56 \\
5.03 \\
3.18 \\
2.21\end{array}$ & $\begin{array}{l}42.43 \\
26.80 \\
20.76 \\
24.99\end{array}$ & $\begin{array}{l}50 \cdot 71 \\
68 \cdot 18 \\
21 \cdot 58\end{array}$ & $\begin{array}{l}6.74 \\
-\overline{9} \\
9.13\end{array}$ & $\begin{array}{l}- \\
- \\
10.77\end{array}$ & $\begin{array}{l}- \\
27.45\end{array}$ \\
\hline Ration Treatments & & etty ac & $\begin{array}{l}\text { id cor } \\
\text { percer }\end{array}$ & $\begin{array}{l}\text { sitio } \\
\text { ge of }\end{array}$ & $\begin{array}{l}n \text { of } a b \\
\text { total }\end{array}$ & $\begin{array}{l}\text { inal } \\
\text { hyl }\end{array}$ & $\begin{array}{l}\text { adipos } \\
\text { esters }\end{array}$ & se tiss & sue \\
\hline Basal (no added fat) & $\begin{array}{l}1.70 \\
(.16)^{1}\end{array}$ & 25.50 & $\begin{array}{l}5.11 \\
(.50)\end{array}$ & $\begin{array}{l}9.28 \\
(.68)\end{array}$ & $\begin{array}{l}36.43 \\
(.74)\end{array}$ & $\begin{array}{r}20.63 \\
(.12)\end{array}$ & $\begin{array}{l}1.29 \\
(.29)\end{array}$ & - & - \\
\hline Animal tallow, 5\% & $\begin{array}{l}2.29 \\
(.09)\end{array}$ & $\begin{array}{l}23.60 \\
(1.37)\end{array}$ & $\begin{array}{l}3.74 \\
(.23)\end{array}$ & $\begin{array}{r}12.58 \\
(.06)\end{array}$ & $\begin{array}{r}39.50 \\
(.50)\end{array}$ & $\begin{array}{r}18.50 \\
(.46)\end{array}$ & $\begin{array}{l}0.00 \\
(.00)\end{array}$ & - & - \\
\hline Animal tallow, $10 \%$ & $\begin{array}{l}2.35 \\
(.03)\end{array}$ & $\begin{array}{r}20.70 \\
(.98)\end{array}$ & $\begin{array}{l}3.88 \\
(.43)\end{array}$ & $\begin{array}{l}11.36 \\
(.04)\end{array}$ & $\begin{array}{l}46.90 \\
(1.68)\end{array}$ & $\begin{array}{r}13.77 \\
(.11)\end{array}$ & $\frac{1.04}{(.40)}$ & - & - \\
\hline Soybean oil, 5\% & $\begin{array}{l}1.91 \\
(1.01)\end{array}$ & $\begin{array}{l}18.75 \\
(2.72)\end{array}$ & $\begin{array}{l}2.15 \\
(1.09)\end{array}$ & $\begin{array}{c}8.80 \\
(1.32)\end{array}$ & $\begin{array}{l}31 \cdot 51 \\
(3 \cdot 91)\end{array}$ & $\begin{array}{l}33.96 \\
(7.81)\end{array}$ & $\begin{array}{l}2.91 \\
(2.25)\end{array}$ & - & - \\
\hline Soybean oil, $10 \%$ & $\begin{array}{l}0.28 \\
(.00)\end{array}$ & $\begin{array}{l}12.97 \\
(.17)\end{array}$ & $\begin{array}{l}0.37 \\
(.07)\end{array}$ & $\begin{array}{l}5.98 \\
(.46)\end{array}$ & $\begin{array}{r}29.68 \\
(.84)\end{array}$ & $\begin{array}{l}46.64 \\
(1.72)\end{array}$ & $\begin{array}{l}4.20 \\
(.32)\end{array}$ & - & - \\
\hline Sunflower seed oil, 5\% & $\begin{array}{l}1.09 \\
(.23)\end{array}$ & $\begin{array}{r}15.57 \\
(.15)\end{array}$ & $\begin{array}{l}1.36 \\
(.24)\end{array}$ & $(.34)$ & $\begin{array}{l}22.30 \\
(.35)\end{array}$ & $\begin{array}{l}50.93 \\
(3.18)\end{array}$ & $\begin{array}{l}1.39 \\
(1.01)\end{array}$ & - & $\overline{-}$ \\
\hline Sunflower seed oil, $10 \%$ & $\begin{array}{l}0.34 \\
(.09)\end{array}$ & $\begin{array}{l}11.15 \\
(.45)\end{array}$ & $\begin{array}{l}0.76 \\
(.20)\end{array}$ & $\begin{array}{l}5.45 \\
(.15)\end{array}$ & 23.54 & $\begin{array}{l}57.26 \\
(.48)\end{array}$ & $\begin{array}{l}1.49 \\
(.33)\end{array}$ & 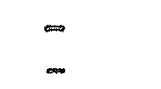 & - \\
\hline Rapeseed oil, 5\% & $\begin{array}{l}0.63 \\
(.10)\end{array}$ & $\begin{array}{l}13.20 \\
(.25)\end{array}$ & $\begin{array}{l}0.93 \\
(.54)\end{array}$ & $\begin{array}{l}4.65 \\
(.52)\end{array}$ & $\begin{array}{l}35.29 \\
(.48)\end{array}$ & $\begin{array}{l}24 \cdot 36 \\
(3.10)\end{array}$ & $\begin{array}{l}2.73 \\
(1.16)\end{array}$ & $\begin{array}{l}8.47 \\
(.91)\end{array}$ & 9.79 \\
\hline Rapeseed oil, $10 \%$ & $\begin{array}{l}0.36 \\
(.10)\end{array}$ & $\begin{array}{l}8.34 \\
(.94)\end{array}$ & $\begin{array}{l}0.63 \\
(.32)\end{array}$ & $\begin{array}{l}2.64 \\
(.92)\end{array}$ & $\begin{array}{l}36.26 \\
(1.08)\end{array}$ & $24 \cdot \frac{17}{80}$ & $\begin{array}{c}4.27 \\
(1.57)\end{array}$ & $\begin{array}{l}9.49 \\
(.55)\end{array}$ & $\begin{array}{l}13.81 \\
(2.87)\end{array}$ \\
\hline
\end{tabular}

\footnotetext{
Figures in parenthesis are standard errors.
} 
acid $\left(C_{18: 2}\right.$ and $\left.C_{18: 3}\right)$ content of this fat source. Inclusion of $10 \%$ soybean oil or $10 \%$ sunflower oil in the ration caused a marked decrease in the palmitic and palmitoleic acid $\left(C_{16}\right.$ and $\left.C_{16: I}\right)$ fractions of adipose tissue with a simultaneous increase in the linoleic acia fraction. The presence of substantial portions of eicosenoic $\left(\mathrm{C}_{20: 1}\right)$ and erucic acid $\left(\mathrm{C}_{22: 1}\right)$ in adipose tissue of poults receiving dietary rapeseed oil is further evidence for an apparent direct deposition of some unaltered dietary fatty acids in body fat stores. 


\section{DISCUSSION}

In general, the addition of animal tallow, soybean oil or sunflower oil to a low fat ration stimulated weight gain and improved efficiency of feed utilization of turkey poults as compared to the basal (low-fat) ration. The ration containing $10 \%$ of soybean oil was an exception to the above so far as weight gain was concerned. This ration significantyy improved efficiency of peed utilization but did not increase weight gain over that obtained by feeding the basal ration.

Increased weight gain and improved feed efficiency due to feeding rations containing soybean oil to chickens were reported by Pepper et al (1953), Yacowitz (1953), Carver et aI (1952) and Dam et aI (1959). In the present, study, soybean oil when used at $5 \%$ of the ration, stimulated growth of poults slightly and significantly improved efficiency of feed utilization, ration metabolizable energy and retention of dietary nitrogen. When used at this level, soybean oil appeared to elicit the same response as did animal tallow and sunflower oil. However, the ration containing $10 \%$ soybean oil failed to stimulate weight gain even though this ration treatment significantly improved efficiency of feed utilizam tion, ration metabolizable energy and nitrogen retention. The explanation for this effect of $10 \%$ soybean oil as 
compared to 5\% soybean oil, or animal tallow and sunflower oil is apparent from the feed consumption data. Poults fed the $10 \%$ soybean oil ration consumed significantiy less feed through 16 weeks of age than did poults fed the basal, 5\% soybean oil, or the animal tallow and sunflower oil rations. Therefore, even though 10\% soybean oil markedly improved feed efficiency, ration metabolizable energy and nitrogen retention as compared to the basal ration, a depression in feed intake prevented a growth stimulation similar to that observed when the $5 \%$ soybean oil ration was red. The factor contained in soybean oil which may have depressed feed consumption when this rat source was used at $10 \%$ of the ration is not apparent. The ration metabolizable energy data indicate that soybean oil contains approximately the same amount of metabolizable energy as animal tallow and sunflower oil. Thus, the total energy content of this particular ration does not appear to have been the factor limiting feed intake.

The fact that rations containing $5 \%$ or $10 \%$ soybean oil possessed essentially the same metabolizable energy as rations containing the same respective levels of animal. tallow or sunflower oil illustrates a difference between the response of chickens and turkeys. Sibbald et al (196I) and Sell and Hodgson (1962) reported that soybean oil was considerably 
higher in metabolizable energy for chickens than was animal tallow. As reported herein, poults failed to respond to dietary soybean oil in this manner.

The stimulation of weight gain induced by the inclusion or $5 \%$ or $10 \%$ animal tallow in the ration was of similar magnitude and was consistent over the entire experimental period. Biely and March (1954), Aitken et al (1954) and Sell and Hodgson (1962) reported that chicks receiving rations containing animal tallow grew significantly faster and more efficiently than those fed a low-fat ration. Similar observations, were reported by Sunde (1954) when turkey poults were the experimental animals.

Concurrent with increased weight gain and improved efficiency of feed utilization observed in this study, due to adding animal tallow to the ration, was a significant increase in ration metabolizable energy and an increase in retention of dietary nitrogen. These observations together with the fact that feed consumption by poults fed animal tallow was not significantly different from that of basal-fed poults, illustrates that animal tallow stimulated weight gain by increasing the utilization of dietary energy and nitrogen for productive purposes.

The inclusion of 5 or 10\% of sunflower oil in the ration exerted an effect essentially parallel to that of 
animal tallow. Sunflower oil stimulated weight gain slightly, improved efficiency of feed utilization, ration metabolizable energy and retention of dietary nitrogen significantIy while exerting little influence on feed consumption. Thus, even though the stimulation of weight gain by sunflower oil was not as great as that by animal tallow, both fat sources appear to elicit a similar response. Sell and Hodgson (1962) also observed a similarity between animal tallow and sunflower oil when included in broiler rations in terms of weight gain stimulation, efficiency of feed utilization and ration metabilizable energy content.

The adition of rapeseed oil to the ration depressed weight gain throughout the experiment as compared to the basal ration. The magnitude of growth depression was directly related to the rapeseed oil content of the ration, at the end of 16 weeks, $5 \%$ and $10 \%$ rapeseed oil depressed weight gain by 0.55 and 1.05 pounds per birds, respectively.

The comparative ration metabolizable energy data indicate that the dietary energy supplied by rapeseed oil was as available to poults as that energy supplied by other fat sources. In addition, 5\% and 10\% rapeseed oil significantly improved efficiency of feed utilization and $10 \%$ rapeseed oil also significantly increased percent nitrogen retention. As was the case with the ration containing $10 \%$ 
soybean oil, the influence of rapeseed oil on weight gain is obvious from the feed consumption data. Poults consuming rations containing 5\% or 10\% rapeseed oil consumed signiricantly less feed than did poults fed the basal ration.

Beare et al (1957),(1958) and (1959) observed that the adition of rapeseed oil to rations markedly depressed growth and feed intake of rats, and the degree of depression was directly related to the level of rapeseed oil in the ration. Thomasson (1955) had previously postulated that the growth inflibiting effect of rapeseed oil was the result of impaired appetite.

In subsequent investigations, Beare et al (1959) showed that erucic acid, a major constituent of rapeseed oil, may be the factor depressing feed intake. They found that reed intake was impaired and weight gain decreased when ethyl eructate was added to rat rations. This evidence suggested a direct influence of erucic acia on feed intake. However, recently, Beare et al (1963) reported that the characteristic effects of rapeseed oil on feed intake and growth of rats could be attributed to the relatively small quantity of palmitic acia contained therein together with a relatively high level of erucic acid. These researchers were able to alleviate most of the growth depressing effect of rapeseed oil on rats by including a 
source of palmitic acid (palm oil) in the ration.

The observation in the current study that rapeseed oil depressed growth of turicey poults is in disagreement with that of Sell and Hodgson (1962) and Tsang et al (1962). These workers reported no detrimental effects of dietary rapeseed oil on broiler chick performance. Sell and Hodgson (1962) found rapeseed oil to be as effective as soybean oil and sunflower oil in promoting weight gain and improving efficiency of feed utilization. Demonstration of such a species difference between turkeys and chickens is not surprising nor unique. Turkeys and chickens differ considerably in response to various nutrients and nutrient levels.

No significant effects of dietary soybean oil, animal. tallow, sunflower oil or rapeseed oil on serum cholesterol concentration were observed, irrespective of the level of dietary fat source used. Miller et al (1962), using, cockerels, reported that lard or com oil supplementation of a low fat ration had little influence on serum cholesterol concentration. Conversely, March and Biely (1959) presented data showing that the addition of animal tallow to chick rations significantly increased serum cholesterol. In general, dietary fat sources have been shown not to greatly affect serum cholesterol level of growing chickens but do alter serum cholesterol concentration of adult chickens (Daghir, 1960). EvidentIy, 
based on data of the current study, growing turkeys, like growing chickens, do not respond appreciably to various dietary fat sources so far as serum cholesterol concentration is concerned. MaNaly (1954) reported that the fat content of edible meat from 12 week-old cockerels increased in direct proportion to the fat content of the diet. Newell et al (1956) observed. that maximum fat deposition in broiler carcasses occurred when rations containing 10 to $15 \%$ fat were fed. Miller et al (1962) have presented data showing that the addition of com oil. or lard to the ration significantly increased the fat content of the breast and thigh muscle of broilers. In the current study, the fat content of thigh (Gastrocnemius.) or breast (Pectoralis minor) muscle of poults 16 weeks of age was not appreciably altered by dietary animal tallow, soybean oil, sunflower oil or rapeseed oil. The discrepancy between the results reported herein and those reported in regard to muscle fat of chicks could be due to the relative maturity of the experimental stock being compared. The chick data was gathered from studies utilizing chicks which have neared the end of the rapid growing period and, at this time, fat deposition will normally occur more readily and can be influenced more easily by dietary fat intake. In contrast, the poults in this investigation had not reached a relative stage of maturity where adipose tissue deposition proceeds at an accelerated 
rate. Evidently a majority of the dietary fat sources was being utilized for energy purposes. Therefore the fat sources had little influence on muscle fat deposition up to the time the experiment was terminated。

In general, fatty acid composition and iodine number of carcass adipose tissue reflected that of the dietary fat, particularly when a $10 \%$ level of the fat source was used. Cruickshank (1934); Adams on et aI (196I) and Rogler and Carrick (I96I) reported that, the degree of saturation of dietary fat had a marked influence on the iodine number of the resulting carcass adipose tissue of chickens and turkeys. Feigenbaum and Fisher (1959) utilizing alkaline isomerization and Sell and Hodgson (1962) using gas chromatography observed that the fatty acid composition of carcass fat of chickens was directly related to the fatty acid composition of the dietary fat.

In the present study, dietary animal tallow caused little change in fatty acid composition of carcass adipose tissue as compared to adipose tissue of basal-fed poults. There was only a slight increase in stearic $\left(C_{18}\right)$ and oleic $\left(C_{18: 1}\right)$ acids. In contrast, feeding soybean oil or sunflower oil markedy increased the linoleic $\left(\mathrm{C}_{18: 2}\right)$ content of carcass fat and there was a concurrent decrease in the palmitic $\left(C_{16}\right)$, stearic $\left(C_{18}\right)$ and oleic $\left(C_{18: I}\right)$ acid fractions. The most 
conclusive evidence of direct deposition of dietary fatty acids in carcass fat is the fact that feeding rapeseed oil resulted in the occurrence of substantial quantities of eicosenoic $\left(\mathrm{C}_{20: 1}\right)$ and erucic $\left(\mathrm{C}_{22: 1}\right)$ acids in carcass adipose tissue. Carcasses of rapeseed oil-fed poults were the only ones which contained measurable quantities of these two fatty acids。 


\section{SUMIIARY AND CONCLUSION}

An evaluation of the influence of dietary soybean oil, sunflower oil, rapeseed oil and animal tallow on weight gains, Peed efficiency, metabolizable energy content of rations, fat deposition in the muscle tissues, and related characteristics of turkey poults has been presented.

Under the conditions of these investigations the rollowing observations were made.

1. The addition of animal tallow, soybean oil or sunflower oil to a low-fat ration stimulated weight gain and improved efficiency of feed utilization. The ration containing $10 \%$ soybean oil was the only exception to the above so far as weight gain was concerned but this ration significantIy improved efficiency of feed utilization.

2. The addition of rapeseed oil to the ration depressed weight gain throughout the experiment as compared to the basal (Iow-iat) ration. The magnitude of growth depression was directly related to the rapeseed oil content of the ration. The comparative ration metabolizable energy data indicate that the dietary energy supplied by rapeseed oil was as available to poults as energy supplied by other fat sources. Poults consuming rations containing $5 \%$ or 10\% rapeseed oil consumed significantly less feed than did poults fed the basal ration. Depressed weight gains 
54

by poults fed rapeseed oil rations was apparently due

to decreased feed consumption.

3. No significant effects of dietary soybean oil, animal tallow, sunplower oil or rapeseed oil on serum cholesterol concentration were observed, irrespective of the level of dietary fat source used.

4. There was no significant difference between ration treat ments with respect to dressing percent and carcass grades.

5. The fat content of thigh (Gastrocnemius ) or breast (Pectoralis minor) muscle of poults 16 weeks of age was not appreciably altered by dietary animal tallow, soybean oil, sunflower oil or rapeseed oil.

6. Fatty acid composition and iodine number of carcass adipose tissue reflected that of the dietary fat, particularly when a $10 \%$ level of the fat source was used.

7. The results of the present study indicate that the composition of the dietary fat may be an important consideration in the production of turkey carcasses for human consumption. Changes in the physical characteristics of carcass fat which may influence cooking loss and the development of off-Plavors are factors that require further study. 


\section{BIBLIOGRAPHY}

I. ADAMSON, I. Fo, G. Ko IEIPER and E。 ROSS, 1961. Influence of dietary fats and cholesterol on tissue lipids in chickens. Jo Nutrition. $73: 247$.

2. AITKEN, J.R. G. S. LINDBALD, and W. G. HUNSAKER。 $1954 \circ$ Beef tallow as a source of energy in broiler rations. Poultry Sci. 33:1038.

3. ARSCOTT, G. H., and I. A. SATHER 1958. Performance data and flavor evaluation of broilers fed diets containing varying amounts of animal fat. Poultry Sci. $37: 844=850$.

4. ASSOCIATION OF OFFICIAI AGRICULTURAL GHEMISTS. 1960. Official. Methods of Analysis. 9th Edition. Menasha, Wisconsin, George Banta Publishing Company.

5. BEARE, J. C. E. R. W。 GREGORY and J.A. CAMPBELI. 1959. The effect of different varieties of rapeseed oil on weight gain, and of golden rapeseed oil on reproduction of the rat. Canad. J. Biochem. Physiol. 37:1191.

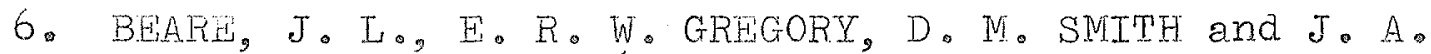
CAMPBEIJ. 196I. The effect of rapeseed oil on reproduction and the composition of rat milk. Canad. J. Biochem. Physiol. 39:195.

7. BEARE, J。I. T.K. MURRAY and J.A. CAMPBELI。 1957. Affect of varying proportions of dietary rapeseed oil on the rat. Canad. Jo Biochem. Physiol. 35:1225.

8. BEARE, J。I。, T。K. MURRAY, H。C。GRICE and J。A. CAPPBELI. 1959b. A comparison of the utilization of rapeseed oil and corn oil by the rat. Canad. J. Biochem. Physiol. 37:613.

9. BEARE, J.I., J.A. CAMPBELI, C.G. YOUNGS, And B. M. CRAIG。 1963. Effects of saturated fat in rats fed rapeseed oil. Canad.J.Biochem. Physiol. 41:605.

10. BAIDINI, J.T., and H.R. ROSENBERG。 1957. The effect of calorie source in chick diet on growth, feed utilization, and body composition. Poultry sci. $36: 432-435$. 
11. BIELY, J. and B. IIARCH. 1954. Fat supplements in chick and poult rations. 2. Poultry Sci. 33:1220.

12. BIEIY, J. and B. MARCH。 1957. Fat and nitrogen retention in chicks fed diets containing different levels of fat and protein. 7. Poultry Sci. 36:1235-124.0.

13. BLAKELY, R. Mo, H. I. MACGREGOR, and JoR. JOWSEY. 1960. Whole rape seed as an energy source in finishing diets for roaster turkeys. Canad. J. Animal. Sci. $40: 67-70$.

14. CARVER, D. S., and E. I. JOHNSON, 1952. Unidentified growth factors in vegetable oils and fatty acids concentrates. Poultry Sci. 31:910-911.

15. CARVER, D.S., E。 E。RTCE, R. E。 GRAY and P.E。 NORE, 1955. Utilization of fats of different melting points added to broiler leeds. Poultry Sci. $34: 544$.

16. CHOMYSZYN, M. 1955. The influence of feed on the quality of fat in geese, Rocz. NankRol., 69:91, 1954. Gited in Nutrition Abstr. Rev., 25:855.

17. COMBS, G. Fo and G。 L。 ROMOSER. 1955. A new approach to poultry feed formulation. Maryland Agx. Exp. Sta. Misc. Publ. No. 226.

18. COMBS, G. F., G. I. ROMOSER and J. I. NICHOLSON. 1956. Effect of added dietary fat and other variables on the performance of broiler chickens. Maryland Agr. Exp. Sta. Misc. Publ. No. 273.

19. CRUICKSHANK, E.M. 1934. Studies in fat metabolism in the foul. 1. The composition of the egg fat and depot fat of the fowl as effected by the ingestion of large amounts of different fats. Biochem. J. $28: 965-977$.

20. CZARNOCKI, J., I. R. SIBBATD and E. V. EVANS. 196I. The determination of chromic oxide in semples of feed and excreta by acid digestion and spectrophotometry. Canad.J.Ani.Sci. 41:167-179.

21. DAN, Ro, R. M。 LEACH, T.S. NETSON, I。 F. W. HIII. 1959. Studies on the effect of quantity and type of fat on chick growth. J. Nutrition, 68:615. 
22. DAGHIR, $\bar{N}_{0} \cdot J_{0}$ and $\mathrm{S}$. I. BALIOUN. 1960. Influence of fats and choline on liver and serum cholesterol in the chick. Poultry sci. 39:1459。

23. DEUEL, H.J.A.I.S. CHENG and M.C. MOREHOUSE. 1948. The digestibility of rapeseed oil in the rat. J. Nutrition, 35:295。

24. DONALDSON, W. E, G。F。COMBS, G. L. ROMOSER and W. SUPPIHE⿰ 1955. Body composition, energy intake, feed efficiency, growth, rate and feather condition of growing chickens as influenced by calorieprotein ratio of the ration. Poultry Sci. 34:1190.

25. DONALDSON, W. E。, G. F。COMBS, G. I. ROMOSER and W。 C。 SUPPLEE. 1957. Studies on energy levels in poultry rations. 2. Tolerance of growing chicks to dietary fat. poultry Sci. 36:807-815.

26. DONALDSON, W. E。, G.F. COIMB, and G.I.ROMOSER. 1956. Studies on energy levels in poultry rations. 1. The effect of calorie-protein ratio of the ration on growth, nutrient utilization and body composition of chicks. Poultry. Sci. 35:1100-1105.

27. DUNCAN, D。B. 1955. Multiple range and multiple Fo tests. Biometrics, 1]:1.

28. FEIGENBAUM, A. S., and H. FISHER. 1959. The influence of dietary fat on the incorporation of fatty acids into the body and egg fat of the hen. Arch. Biochem. Blopkys. 79:302.

29. HENDERSON, E. Wo, and W。 E. IRWIN。 I940. The tolerance of growing chicks for soybean oil in their ration. Poultry Sci. 19:389。

30. HIII, F. W. and D. L. ANDERSON. 1958. Comparison of metabolizable energy and productive energy determinations with growing chickens. Jo Nutrition $64: 587$.

31. LEONG, K. C., N. L。SUNDE, H. R.BIRD, and C.A. ELVEHGEM, 1955. Effect of energy, protein ratio on the growth rate, efficiency, feathering and fat deposition in chickens. Poultry Sci. 34:1206.

32. LEONG, K. C., M. L. SUNDE, H.R.BIRD, and C.A. ELVEHGEM。 1959. Interrelationship among dietary energy, protein and amino acids for chickens. Poultry sci. 38:1267-1285. 
33. MARCH, B。 and J.BIELY, 1957. Fat studies in poultry. 6. Utilization of fats of different melting points. Poultry Sci. 36:71-75。

34. MARCH, B. and J.BIELY. 1959. Dietary modification of serum cholesterol in the chick. Jo Nutrition. 69:105-110。

35. MCNALIY, E. H. 1954. Observations on the use of fats in the finishing diets of Pryers. Poultry Scj. $33: 1071$ 。

36. MENGE, Ho and C.A. DENTON. 196I. Effect of dried egg yolk, oils and fat on chick growth. J. Nutrition $75: 107-115$.

37. MILIER, E. C., H. MENGE and C。A.DENTON。 I962。 Effect of dietary fat on tissue fat and plasma cholesterol level in broilers. Poultry Sci. 41:970。

38. NEWELI, G. N。, J.I. FRY and R.H.THAYER, 1956. The effect of fat in the ration on fat deposition in broilers. Poultry Sci. 35:1163.

39. PEPPER, W.F., S.J.SLINGER and E.S.SUYDER。 1953. Value of low levels of soybean oil in broiler diets containing a high percentage of wheat. Poultry Sci. 32:1084。

40. RAND, N。T. H. M. SCOTT and F。A. KUMMERON. 1958. Dietary fat in the nutrition of the growing chick. Poultry Sci. 37:1075-1085.

41. RENAER, R。 and F'W HILI, 1958. Metabolizable energy values of fats and fatty acias for chickens. Proc。 Cornell Nutrition Conference, pp.95-100.

42. ROGLER, J。 $C$, and $C$ 。W. GARRICK, 196I. Studies with unextracted soybeans for chickens and turkeys. Feedstufis。 $33(4): 26$ 。

43. SCOTT, H.M., I。D.MATTERSON and E。 P.SINGSEN, 1947. Nutrition factors influencing growth and efficiency of feed utilization. 1. The effect of the source of carbohydrate. Poultry Sci. 26:554. 
44. SCOTI, H. M。, I. C.SIMS and D. L。SLAKLI, 1955。 The effect of varying protein and energy on performance of chicks, Poultry Sci. 34:1220.

45. SCHWEIGERT, B. S. 1952. New developments in nutrition. Sowest. Vet. $5: 245-247$.

46. SEII, J。I. and G. G.HODGSON。 1962. Comparative value of dietary rapeseed oil, sunflower seed oil, soybean oil and animal tallow for chickens. J。 Nutrition 76 : 113-118.

47. SIBBALD, I.R., S. J。 SLINGER and G. C. ASHTON. 1961. Factors effecting the metabolizable energy content of poultry feeds. 2. Poultry sci. 40:303.

48. SIEDLER, J.A. and B.S.SCHWEIGERT. 1953. Effect of feeding graded levels of fat with and without choline and antibiotic $+B_{12}$ supplements to chicks. Poultry sci. 32:449-454。

49. SUNDE, M. L., 1956. A relationship between protein level and energy level in chick rations. poultry Sci. $35: 350$.

50. SUND, M. L., 1954. The use of animal fats in poultry feeds. JoAmer。 Oil Chem.Soc. 31:49.

51. SUNDE, M。I. J。R。 VEDVIK, H。 W。 BURINS, W。W。 CRAVENS. 1952. Effect on growth of supplements to chick rations containing Vitamin $B_{12}$ and antibiotics. Poultry Sci. 31:571-576。

52. THONASSON, H.J. and Jo BOLDINGH. 1955. The biological value of oils and fats. I. Growth and food intake of feeding with natural oils and fats. J. Nutrition. $56: 455-468$.

53. THOMASSON, H.J. and J. BOLDINGH. 1955. The biological value of oils and Iats. 2. The growth retarding substance in rape seed oil, Jo Nutrition. 56:469-475.

54. TSANG, S.T.I., E.I.MCKEE, G。P.ANDREWS and H。A.WINDSOR。 1962. The value of rapeseed screening oil in broiler rations. World Poultry Sci. Jo 18: N2。142-146。 
55. VERMEULEN, M. C. 1932. Nutritional syndromes induced in white leghorn chickens reared on various synthetic diets. Thesis for the Master of Science degree of Iowa State College.

56. WAIBEI, P. F, 1955。 Effect of dietary protein level and added tallow on growth and carcass composition of chicks. Poultry Sci. 34:1226.

57. WAIBEE, P. E. 1958. Elffectiveness of unknown growth factors, antibiotic, and anirial fat in turkey poult rations. Poultry Sci. $37: 1144$.

58. YACOWITZ, $H$. and V.D.CHAMBERLIN. 1954. Further studies on the supplementation of broiler rations with fats. Poultry sci. 33:1090。

59. YACOWITZ, H. 1953. Supplerentation of corn soybean oil meal ration with penicillin and various fats. Poultry Sci. 32:930.

60. ZIATKIS, A., B, ZAK and $H_{0} J . B O Y L E$ 1953. A new method for the direct determination of serum cholesterol. J. Lab. CIin. Med. 4I:486. 
Table $I$

Comparative Effects of Dietary Fat on Weight Gains

\begin{tabular}{|c|c|c|c|c|c|c|}
\hline $\begin{array}{l}\text { Ration } \\
\text { Treatment }\end{array}$ & 2 Weeks & $\begin{array}{r}\text { Me } \\
4 \text { weeks }\end{array}$ & $\begin{array}{l}\text { a weight } \\
6 \text { weeks }\end{array}$ & in 8 weeks & 12 Weeks & 16 weeks \\
\hline & $\left(g m_{0}\right)$ & $\left(g m_{0}\right)$ & $\left(g m_{0}\right)$ & $\left(1 \mathrm{~b}_{0}\right)$ & $\left(1 b_{0}\right)$ & $\left(1 b_{0}\right)$ \\
\hline Basal & 142 & 526 & 1251 & 4.70 & 9.80 & 14.85 \\
\hline $\begin{array}{ll}\text { Soybean oil, } & 5 \% \\
\text { Soybean oil, } & 10 \%\end{array}$ & $\begin{array}{l}146 \\
127\end{array}$ & $\begin{array}{l}563 \\
517\end{array}$ & $\begin{array}{l}1411 \\
1262\end{array}$ & $\begin{array}{l}4.85 \\
4.70\end{array}$ & $\begin{array}{l}9.85 \\
9.55\end{array}$ & $\begin{array}{l}15.25 \\
14.80\end{array}$ \\
\hline $\begin{array}{ll}\text { Sunflower oil, } & 5 \% \\
\text { Sunflower oil, } & 10 \%\end{array}$ & $\begin{array}{l}148 \\
123\end{array}$ & $\begin{array}{l}547 \\
522\end{array}$ & $\begin{array}{l}1306 \\
1277\end{array}$ & $\begin{array}{l}4 \cdot 75 \\
4 \cdot 75\end{array}$ & $\begin{array}{l}9.65 \\
9.60\end{array}$ & $\begin{array}{l}15 \cdot 15 \\
15.25\end{array}$ \\
\hline $\begin{array}{ll}\text { Rapeseed oil, } & 5 \% \\
\text { Rapeseed oil, } & 10 \%\end{array}$ & $\begin{array}{l}116 \\
116\end{array}$ & $\begin{array}{l}427 \\
479\end{array}$ & $\begin{array}{l}1128 \\
1046\end{array}$ & $\begin{array}{l}4.00 \\
4.20\end{array}$ & $\begin{array}{l}8.85 \\
8.40\end{array}$ & $\begin{array}{l}14.25 \\
13.80\end{array}$ \\
\hline $\begin{array}{ll}\text { Animal tallow, } & 5 \% \\
\text { Animal tallow, } & 10 \%\end{array}$ & $\begin{array}{l}144 \\
138\end{array}$ & $\begin{array}{l}528 \\
543\end{array}$ & $\begin{array}{l}1338 \\
1328\end{array}$ & $\begin{array}{l}4.95 \\
4.85\end{array}$ & $\begin{array}{r}10.30 \\
9.75\end{array}$ & $\begin{array}{l}15 \cdot 40 \\
15 \cdot 40\end{array}$ \\
\hline
\end{tabular}


Table 2

Comparative Effects of Dietary Fats on Efficiency of Feed Utilization

\begin{tabular}{lllllll}
\hline Ration & \multicolumn{5}{c}{ Feed per Gain } \\
Treatment & 2 Weeks & 4 Weeks & 6 Weeks & 8 Weeks & 12 Weeks & 16 Weeks \\
\hline Basal & 1.67 & 1.84 & 1.87 & 2.04 & 2.47 & 3.01 \\
Soybean 0il, 5\% & 1.46 & 1.65 & 1.60 & 2.01 & 2.34 & 2.80 \\
Soybean oil, 10\% & 1.44 & 1.53 & 1.60 & 1.86 & 2.12 & 2.45 \\
Sunflower oil, 5\% & 1.44 & 1.63 & 1.65 & 2.08 & 2.38 & 2.77 \\
Sunflower oil, 10\% & 1.51 & 1.55 & 1.60 & 1.86 & 2.24 & 2.69 \\
Rapeseed oil, 5\% & 1.69 & 1.84 & 1.84 & 1.98 & 2.34 & 2.74 \\
Rapeseed oil, 10\% & 1.68 & 1.77 & 1.75 & 1.80 & 2.18 & 2.55 \\
Animal tallow, 5\% & 1.55 & 1.77 & 1.75 & 2.00 & 2.14 & 2.69 \\
Animal tallow, 10\% & 1.55 & 1.65 & 1.66 & 1.88 & 2.21 & 2.69 \\
& & & & & & \\
\hline
\end{tabular}


Table 3

Analysis of Variance of Weight Gains And

Feed Ericiency At 2 weeks of Age

\begin{tabular}{lccc}
\hline Source of & $\begin{array}{c}\text { Degrees of } \\
\text { Fariation }\end{array}$ & Wreedom & Tiean Squares \\
Blocks & 2 & 381.7 & $0.024 *$ \\
Treatment & 8 & $489.2 * *$ & $0.033 * *$ \\
Error & 16 & 108.2 & 0.004 \\
Total & 26 & &
\end{tabular}

* Statistically significant at $P<0.05$

** Statistically signiricant at $P<0.01$ 
Table 4

Analysis of Variance of Weight Gains And

Feed Efficiency At 4 Weeks of Age

\begin{tabular}{lccc}
\hline \hline Source of & $\begin{array}{c}\text { Degrees of } \\
\text { Freedom }\end{array}$ & Weight Gains & $\begin{array}{c}\text { Mean Squares } \\
\text { Variation }\end{array}$ \\
Blocks & 2 & 2580.5 & 0.01 \\
Treatments & 8 & $7801.8 * \%$ & $0.04 \% *$ \\
Error & 16 & 770.8 & 0.004 \\
Total & 26 & & \\
\end{tabular}

** Statistically significant at $P<0.01$

a Mean squares for treatment not significant at $P<0.05$ 
Pable 5

Analysis of Variance of Weight Gains And Feed Efficiency At 6 weeks of Age

\begin{tabular}{lccc}
\hline \hline $\begin{array}{l}\text { Source of } \\
\text { Variation }\end{array}$ & $\begin{array}{c}\text { Degrees of } \\
\text { Freedom }\end{array}$ & Weight Gains & $\begin{array}{c}\text { Mean } \\
\text { Feed Ffficiency }\end{array}$ \\
Blocks & 2 & 3453.3 & 0.001 \\
Treatments & 8 & $37161.2 * *$ & $0.029 \%$ \\
Error & 16 & 4774.8 & 0.008 \\
Total & 26 & & \\
& & & \\
* Statistically significant at $P<0.05$ & \\
* Statistically significant at $P<0.01$ &
\end{tabular}


Table 6

Analysis of Variance of Weight Gains And Feed Efficiency At 8 Weeks of Age

\begin{tabular}{|c|c|c|c|}
\hline $\begin{array}{l}\text { Source of } \\
\text { Variance } \\
\end{array}$ & $\begin{array}{l}\text { Degrees of } \\
\text { Freedom }\end{array}$ & $\begin{array}{r}\text { Mea } \\
\text { Weight Gains } \\
\end{array}$ & $\begin{array}{l}\text { Squares } \\
\text { Feed Efriciency }\end{array}$ \\
\hline Blocks & 1 & & 0.015 \\
\hline Treatments & 8 & $0.205 * *$ & 0.019 \\
\hline Error & 8 & 0.031 & 0.006 \\
\hline Total & 17 & & \\
\hline
\end{tabular}

** Statistically significant at $\mathrm{P}<0.01$ 
Table 7

Analysis of Variance of Weight Gains And Feed Efficiency At 12 Weeks of Age

\begin{tabular}{|c|c|c|c|}
\hline $\begin{array}{l}\text { Source of } \\
\text { Variation }\end{array}$ & $\begin{array}{l}\text { Degrees of } \\
\text { Freedom }\end{array}$ & $\begin{array}{r}\text { Niear } \\
\text { Weight Gains }\end{array}$ & $\begin{array}{l}\text { Squares } \\
\text { Feed Efficiency }\end{array}$ \\
\hline BIocks & 1 & 0.027 & 0.0129 \\
\hline Treatments & 8 & $0.644 * x$ & $0.0287 * 6$ \\
\hline Error & 8 & 0.064 & 0.0046 \\
\hline Total & 17 & & \\
\hline
\end{tabular}

* Statistically significant at $\mathrm{P}<0.01$ 
Table 8

Analysis of Variance of weight Gain And Feed Efficiency At 16 Weeks of Age

\begin{tabular}{lccc}
\hline $\begin{array}{l}\text { Source of } \\
\text { Variation }\end{array}$ & $\begin{array}{c}\text { Degrees of } \\
\text { Freedom }\end{array}$ & Weight Gains & $\begin{array}{c}\text { Mean Squares } \\
\text { Feed Efficiency }\end{array}$ \\
\hline Blocks & 1 & $0.613 *$ & 0.006 \\
Treatments & 8 & 0.126 & $0.050 \%$ \\
Error & 8 & & 0.007 \\
Total & 17 & & \\
\hline
\end{tabular}

* Statistically significant at $P<0.05$

** Statistically significant at $P<0.01$ 
Table 9

Analysis of Variance Of Metabolizable Energy And Nitrogen Retention of Rations Containing Different Fat Sources As Determined With Turkey Poults From 5 To 6 Weeks Of Age

\begin{tabular}{lccc}
\hline $\begin{array}{l}\text { Source of } \\
\text { Variation }\end{array}$ & $\begin{array}{c}\text { Degrees of } \\
\text { Freedom }\end{array}$ & $\begin{array}{l}\text { Metabolizable } \\
\text { Energy }\end{array}$ & $\begin{array}{c}\text { Mitrogen } \\
\text { Retention }\end{array}$ \\
\hline Blocks & 2 & 0.0010 & 0.0070 \\
Treatments & 8 & $0.2025 * *$ & $0.0952 * *$ \\
Errors & 16 & 0.0009 & 0.0116 \\
Total & 26 & & \\
\hline
\end{tabular}

** Statistically significant at $P<0.01$ 
Table 10

Analysis of Variance For Ether Extracts of Pectoralis Minor And Gastrocnimius Muscles

\begin{tabular}{lccc}
\hline $\begin{array}{l}\text { Source of } \\
\text { Variation }\end{array}$ & $\begin{array}{c}\text { Degrees of } \\
\text { Freedom }\end{array}$ & $\begin{array}{c}\text { Mean Squares } \\
\text { Gastorocanemius } \\
\text { Muscle }\end{array}$ & $\begin{array}{c}\text { Mectis } \\
\text { Minor Muscle }\end{array}$ \\
\hline Blocks & 1 & 0.4997 & 0.102 \\
Treatments & 8 & 0.6687 & 0.262 \\
Error & 8 & 0.7839 & 0.362 \\
Total & 17 & & \\
\hline
\end{tabular}

$a$ and $b:-$ Mean squares not significant at $P<0.05$ 
Table 11 Analysis of Variance on Blood Serum Cholesterol At 6, 12 And
16 Weeks of Age

\begin{tabular}{lccccc}
\hline Source of & Degree of Freedom & \multicolumn{3}{c}{ Mean Square } \\
Variation & 6 weeks & $\begin{array}{c}12 \text { and } \\
16 \text { Weeks }\end{array}$ & 6 Weeks & 12 Weeks & 16 Weeks \\
\hline Blocks & 2 & 1 & 1147.45 & 49.67 & 174.84 \\
Treatments & 8 & 8 & 822.08 & 242.27 & 79.56 \\
Error & 16 & 8 & 352.42 & 365.82 & 60.89 \\
Total & 26 & 17 & & & \\
\hline
\end{tabular}

$a$ and $b:-$ Mean squares not significant at $P<0.05$ 
Table 12

Analys is of Variance of The Transformed Data Pertaining To Dressed Weight And Carcass Grades As A Percentage of Live weight

\begin{tabular}{lccc}
\hline $\begin{array}{l}\text { Source of } \\
\text { Variation }\end{array}$ & $\begin{array}{c}\text { Degree of } \\
\text { Freedom }\end{array}$ & Dressed Weight & $\begin{array}{c}\text { Mean Square } \\
\text { Carcass Grades }\end{array}$ \\
\hline Blocks & 1 & 0.035 & 55.70 \\
Treatments & 8 & 1.630 & 13.34 \\
Jirror & 8 & 0.830 & 17.10 \\
Total & 17 & & \\
\end{tabular}

$a$ and $b:-$ Mean squares not significant at $P<0.05$ 
Table 13

Analysis of Variance on The Iodine Values of Abdominal Adipose Tissue

\begin{tabular}{lcrr}
\hline $\begin{array}{l}\text { Source of } \\
\text { Variation }\end{array}$ & $\begin{array}{l}\text { Degree of } \\
\text { Freedor }\end{array}$ & $\begin{array}{l}\text { Mean } \\
\text { Squares }\end{array}$ & E \\
\hline Blocks & 1 & 4.204 & 1.41 \\
Treatments & 8 & 673.530 & $225.64 * *$ \\
Error & 8 & 2.985 & \\
Total & 17 & & \\
\end{tabular}

* Statistically signiricant at $P<0.01$ 